\title{
norden
}

Nordic Council of Ministers

Ved Stranden 18

DK-1061 Copenhagen K

www.norden.org

NORDISKE ARBEJDSPAPIRER

NORDIC WORKING PAPERS

\section{Efficacy Assessment of Treated Articles}

A guidance

Peter Askew, IMSL

http://dx.doi.org/10.6027/NA2014-904

NA2014:904

ISSN 2311-0562

This working paper has been published with financial support from the Nordic Council of Ministers. However, the contents of this working paper do not necessarily reflect the views, policies or recommendations of the Nordic Council of Ministers. 



\title{
Efficacy Assessment of Treated Articles A guidance
}

\author{
Peter Askew, IMSL \\ www.imsl-uk.com
}




\section{Contents}

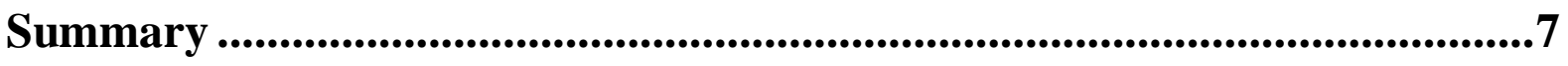

Sammanfattning..................................................................................................9

Objective..................................................................................................................11

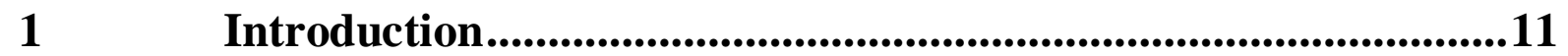

1.1 Understanding the Problem, and the Purpose of a Biocidal Treatment ................................ 11

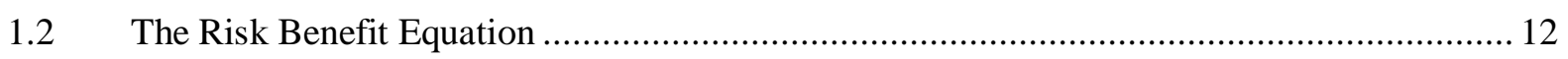

1.3 The Difficulty with Setting Performance Criteria .............................................................. 13

2 The Role of Biocides in Materials and Articles...........................16

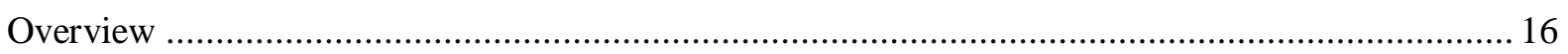

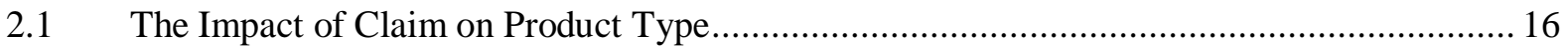

2.2 Demonstrating that a Biocide is required ...................................................................... 17

$3 \quad$ Protection of a Material/Article and its Properties .....................19

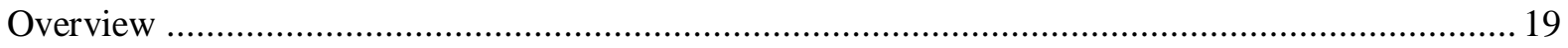

3.1 Protecting the Properties of a Material.............................................................................. 20

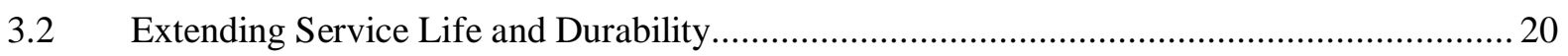

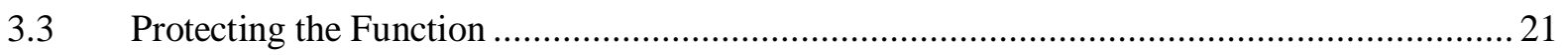

3.4 Determining the Level of Performance Required ................................................................. 22

3.5 Demonstrating the Need and Measuring the Effect …......................................................... 22

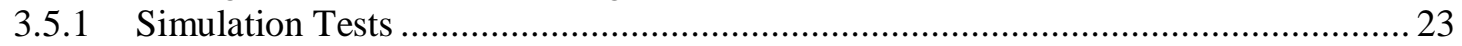

3.5.2 Laboratory Tests Based on Artificial Growth Media................................................ 25

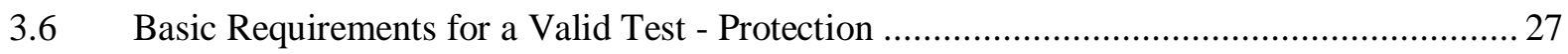

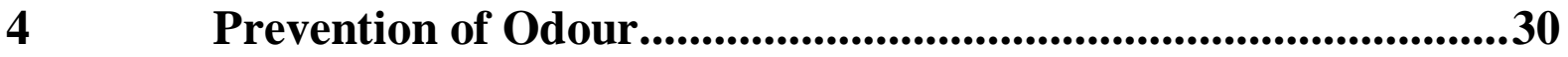

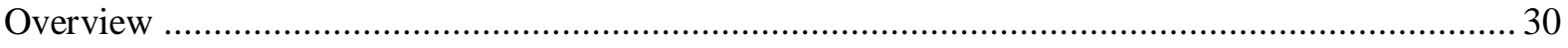

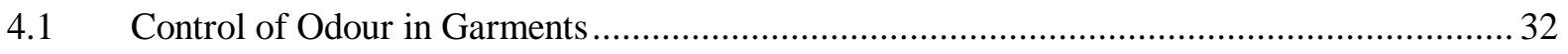

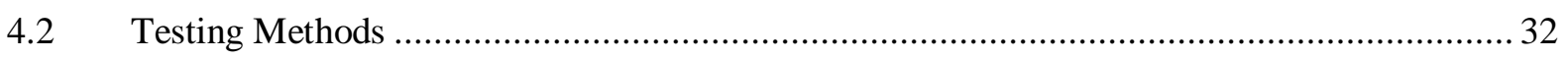

$5 \quad$ Materials and Articles Treated to Add New Properties and Functions not Related to the Primary Use ........................................37

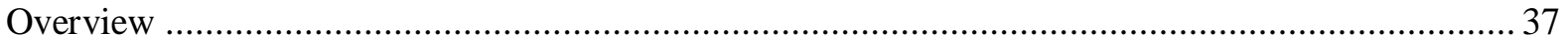

$5.1 \quad$ Determining the Purpose of the Treatment …...................................................................... 37 
5.2 Supporting Claims

5.2.1 Effects Intended to Inhibit Growth and Survival................................................... 41

5.2.2 Applications that Intend to Kill Organisms through Contact ..................................... 44

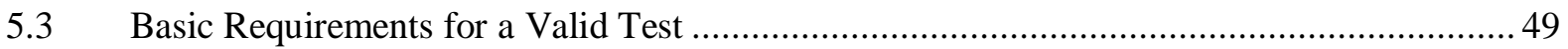

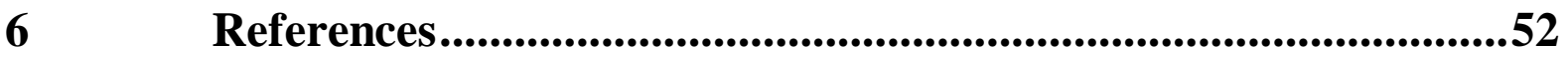

Appendix A: Methods to Measure the Effects of Protecting Material........54

Appendix B: Methods to Measure Antimicrobial Activity ............................62

Appendix C: The Role of MIC Data in Supporting Claims for Treated Materials ............................................................................71 


\section{Index of Figures and Tables}

Figure 1: $\quad$ Mould Growth on a Painted Surface........................................................... 14

Figure 2: Microbial Growth on a Plasticised PVC Shower Curtain ................................. 15

Figure 3: Flow Diagram to Determine the Nature of the Biocidal Treatment and locate the relevant section in this document................................................................. 18

Figure 4: Fungal and Algal Growth on a Façade........................................................ 21

Figure 5: Example of a Simulated Growth Test........................................................ 24

Figure 6: The Effect of the Termite, Coptotermes formosanus on Wood-Plastic Composite

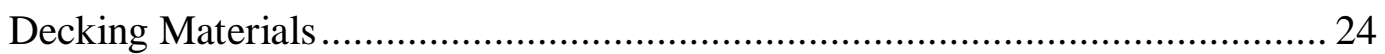

Figure 7: An Example of an Agar Plate Based Test ....................................................... 26

Box 1: $\quad$ Basic Requirements for a Valid Test Protection ............................................. 28

Table 1: $\quad$ Protection - Example Claims, Problems and Testing Approaches ..................... 28

Figure 8: An Agar Plate Based Test for Textiles............................................................ 33

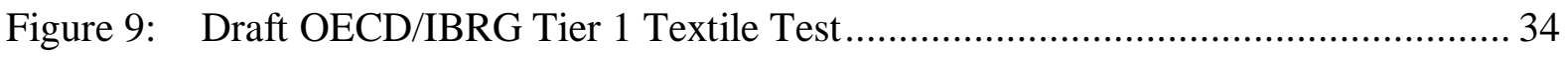

Table 2: Odour: Example Claims, Problems and Testing Approaches ............................ 36

Table 3: Cascade Showing the Various Parties Involved in the Supply Chain for Treated

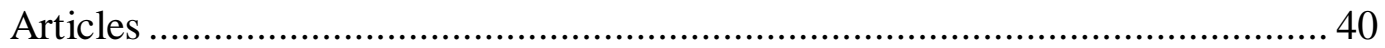

Figure 10: A Test for Measuring Basic Antibacterial Properties of Non-Porous Materials.. 43

Figure 11: Example Test Protocol for Measuring the Activity of Non-Porous Treated Materials on Splashes of Contaminated Liquids ............................................. 46

Figure 12: Example Test Protocol for Measuring the Activity of Porous Treated Materials on Splashes of Contaminated Liquids

Figure 13: Determining the Antibacterial Activity of Surfaces using a Non-Suspended

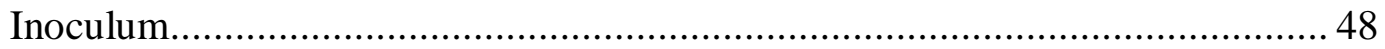

Table 4: $\quad$ Added Properties - Example Claims, Problems and Testing Approaches .......... 50

Box 2: $\quad$ Basic Requirements for a Valid Test Added Properties.................................... 51

\section{Index of Method Overview in the Appendices A and B}

Table I: Methods used to Examine the Resistance of Porous Materials to Biodeterioration:

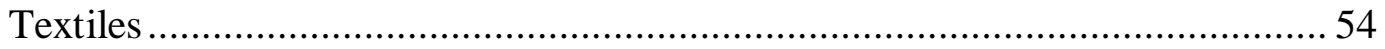

Table II: Methods used to Examine the Resistance to Biodeterioration: Geotextiles......... 55

Table III: Methods used to Examine the Antimicrobial Activity and Microbial Resistance of

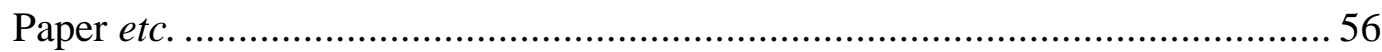

Table IV: Methods used to Examine the Resistance to Biodeterioration: Plastics .............. 57

Table V: Methods used to Examine the Antimicrobial Activity and Microbial Resistance of Surface Coatings \& Adhesives ................................................................. 59 
Table VI: Methods used to Examine the Antimicrobial Activity of Textiles (fabric, yarn or

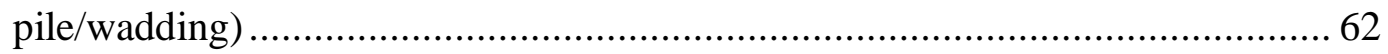

Table VII: Methods used to Examine the Antimicrobial Activity of Carpets...................... 67

Table VIII: Methods used to Examine the Antimicrobial Activity of Non-Porous Surfaces.. 69 


\section{Summary}

Articles treated with biocides can be divided into two major groups: one where the biocide preserves the functions of the article itself; and, the other where new properties are introduced by the biocidal treatment.

In the first major group, the treatment is intended to protect the material or article itself from deterioration or to prolong service life. To substantiate such a claim, the function of the articles/materials or their durability have to be compared with an untreated variant. In this way, the benefit of the treatment in terms of economic or environmental impact can be demonstrated. When this is clear, a more accurate judgement of risk vs. benefit can be made during the evaluation of the active substance(s) involved. There are a wide range of test methodologies that can be used (or modified) to demonstrate the effect; when applied in combination with ageing and pre-treatments, even long-term effects can be shown. The one area that at present cannot be tested with ease is the prevention of odour in garments and shoes. Data from wearing trials and the like must be used to demonstrate effects (although some laboratory-based tests can be used to add supporting evidence).

The other major group are materials or articles that are treated to introduce new properties. The most common of these are related to perceived hygienic benefits. These range from preventing the growth of bacteria that may affect the health of people and livestock to articles with properties intending to kill organisms on contact. The claims made for such effects are varied and range from the highly specific ('these pyjamas are treated to remove MRSA from the skin prior to admission to hospital') to the very vague ('antibacterial!'). To understand the effects which these types of materials and articles are intended to have, requires a clear explanation of what the problem is and how the use of the article will reduce or eliminate it. For example, if a material is treated to prevent growth then it must be shown that growth does indeed occur under normal conditions of use and that the treatment prevents this. It should also be made clear why this is of benefit. Articles that are intended to kill organisms that come into contact with them should be tested to show this effect under the normal conditions of use, and when the target species are introduced into the test system in the manner in which they would be in practice. The speed, scale and duration of the effect should be shown to deliver the benefit claimed (if a door handle is treated to reduce the spread of nosocomial infections it must be shown that this effect is achieved when relevant organisms are presented through skin contact - simulated or otherwise - and the effect is of sufficient speed and size that it can produce a significant benefit in use). Although there are a large number of methods that can detect basic antimicrobial properties in such materials, none are suitable without, often, extensive modification, to demonstrate effects in practice. Therefore data that supports such claims must be generated using tests that are tailor-made (i.e. tests that 
reproduce the conditions under which growth/survival could occur, that present the target species in a way that simulates skin contact or is delivered via aerosols etc.).

Effects related to perceived health benefits are not restricted to microorganisms. Textiles might be treated with repellents or insecticides which intend to protect their wearer from biting insects (e.g. Mosquitoes). Laboratory tests would need to show that the treatment kills or repels the insects with sufficient speed and efficacy that biting does not occur; otherwise the intended function would not be realised.

Only by demonstrating why a treatment is required, how it is achieved and what benefit it delivers can valid assessments be made of risk vs. benefit for active substances used in treated articles and treated materials. 


\section{Sammanfattning}

Varor som är behandlade med biocider kan delas in i två huvudgrupper: en grupp där biocidens funktion är att bevara själva varan och en annan där biocidbehandlingen tillför varan nya egenskaper.

I den förstnämnda huvudgruppen syftar behandlingen till att skydda materialet eller själva varan från att försämras. För att styrka ett sådant påstående måste varan/materialets funktion och hållbarhet jämföras med motsvarande för en obehandlad vara. På så vis kan man påvisa fördelen med behandlingen vad beträffar ekonomisk eller miljömässig betydelse. Då detta tydliggjorts kan man bättre bedöma risken gentemot nyttan vid utvärdering av de aktiva ämnen som ingår. Det finns ett stort urval av testmetoder som kan användas (eller anpassas) för att påvisa en effekt; när dessa utförs i kombination med åldringsprocesser och förbehandlingar kan man till och med påvisa långtidseffekter. Det man i nuläget inte kan testa på ett enkelt sätt är motverkande av lukt i kläder och skor. För att påvisa sådana effekter måste data från experiment där försökspersoner får bära plagg och lukten sedan testas av en luktpanel användas (vissa laboratorietest kan dock användas som stödjande bevisning).

Den andra huvudgruppen utgörs av material eller varor som är behandlade i syfte att tillföras nya egenskaper. Dessa egenskaper är vanligen sådana som upplevs vara hygieniska, som t.ex. förebygger bakterietillväxt (bakteriostatiskt) eller egenskaper som avser att döda organismer vid kontakt (bakteriozid). Påståenden som görs om sådana effekter är brokiga och varierar mellan att vara mycket specifika ("den här pyjamasen är behandlad för att avlägsna MRSA från huden inför inläggning på sjukhus”) till att vara väldigt diffusa ("antibakteriell!”). För att förstå de effekter som dessa material och varor är avsedda att ha krävs det en tydlig förklaring av själva grundproblemet och hur en användning av varan kommer att reducera eller eliminera det. Om till exempel ett material behandlats i syfte att förhindra tillväxt måste det visas att tillväxt faktiskt skulle ske under normala användningsvillkor och att behandlingen kan förhindra detta. Det ska också framgå varför tillväxten är ett problem. Varor som är avsedda att döda organismer som kommer i kontakt med dem bör testas så att effekten påvisas under normala användningsvillkor samt då test organismen introduceras i test systemet på ett sätt som också sker i praktiken. För att vara förenlig med ett påstående om en viss nytta måste hastigheten, storleken och varaktigheten av effekten visas (om ett dörrhandtag behandlats för att förhindra spridning av nosokomiala infektioner måste det visas att effekten uppnås vid hudkontakt med relevanta organismer (simulerad eller på annat sätt) och att effekten uppnås tillräckligt snabbt och med tillräcklig effektivitet för att användningen ska anses ge en betydande vinst). Trots att det finns ett stort antal metoder som kan detektera grundläggande antimikrobiella egenskaper i dessa material finns det inga som är lämpliga utan att först behöva modifieras för att visa effekter under verkliga 
förhållanden. Därför måste data som ska stödja den här typen av påståenden genereras med hjälp av skräddarsydda tester (det vill säga test som återspeglar förhållanden där tillväxt/överlevnad är möjlig och där målorganismen tillförs på ett sätt som efterliknar hudkontakt eller tillförsel genom aerosol etc.)

Effekter som upplevs vara till fördel ur hälsosynpunkt rör inte bara mikroorganismer. Textilier kan behandlas med avskräckande medel eller med insekticider avsedda att skydda användaren från stickande insekter (till exempel myggor). För sådana användningar skulle det behöva visas i laboratorietest att behandlingen dödar eller avvisar insekterna så snabbt och effektivt att stickande inte sker; annars verkställs inte den avsedda funktionen.

Bara då man visat varför en behandling behövs, hur den åstadkommes och vad fördelen med denna är kan man göra en meningsfull bedömning av risken gentemot nyttan med den aktiva substansen och de behandlade materialen.

Bara då man kan visa varför en behandling krävs, hur man åstadkommer den och vilken nytta den kan ge, kan man bedöma risken kontra nyttan av de verksamma ämnen som används i behandlade varor och behandlade material. 


\section{Objective}

The purpose of this document is to provide guidance for applicants and competent authorities on the efficacy testing of biocides used in materials and treated articles. It shall help define the problem that the use of a biocide is intended to solve. This, along with service expectations, will help define the type of data that would be required to support any claim made in a meaningful way. The presence and relevance of existing standard test methods will be described and, where they do not exist or where they do not provide sufficient support, the nature of the data required will be described.

This document will structure possible claims for treated articles and treated materials. It will provide, through examples and background information, guidance on different types of claims and how to support them by providing data that is relevant to actual use. At the same time, it raises awareness of the limitations of certain testing regimes in supporting specific claims. The document cannot be exhaustive but shall help with the understanding of the underlying principles for formulating the benefits of a biocidal treatment of a material or article. This is the prerequisite for risk vs. benefit judgements.

\section{Introduction}

\subsection{Understanding the Problem, and the Purpose of a Biocidal Treatment}

One of the fundamental pre-requisites for understanding the role that a biocidal active substance/product must fulfil is an understanding of the problem that it is intended to resolve. The deterioration of natural products such as wood and wool through the action of biological agents, whether microorganisms or insects etc., is familiar and has been associated with them since they were first used by mankind (e.g. Ref. 1). Similarly, there has been a long history of the use of chemical and physical measures to prevent their biodeterioration. With other, especially man-made products such as plastics, the need for protection against biological activity is often less obvious for the end-user. In many cases, the general public is unaware that biocides are even incorporated into them. Even when a biocidal treatment is openly promoted, claims for the antimicrobial (especially antibacterial) properties of treated articles and materials are often unclear and poorly defined. In many cases end-users and consumers have little understanding of the benefit that can be expected and whether it is delivered by a product in actual use. For example, when one purchases a hard surface disinfectant, one expects that it kills microorganisms on the surface that is cleaned with it. However, when one purchases a dishwashing sponge that claims to be antibacterial it is far from clear what it is intended to do. Does it mean that 
surfaces wiped with it are disinfected? Is it killing bacteria while you wash the dishes or does it mean that bacteria will not grow on the sponge when it is left moist beside the sink? And for how long will it continue to function for? Many such products lack clarity of purpose.

With all biologically active substances there is a balance to be made between any negative aspects of their properties to man and the environment and the benefits that their use may bring. In some cases the presence of a biocide will enhance or extend the performance of a material whereas in others it will be essential to achieve that performance in the first place. For example, many of the current water-based formulations could not be manufactured without an in-can preservative. In the past, the presence of solvents etc. rendered the products non-susceptible to microbiological attack. A water-based paint, free of volatile organic compounds (VOCs), could not exist without the use of a biocide. Likewise, many materials manufactured from plasticised PVC would soon become fouled by surface growths of fungi and lose plasticity and crack without the inclusion of a fungicide (Ref. 2). In these examples the biocide is adding a vital function to the material/article. For others, the value that the presence of a biocide brings is in extending their durability, as with facade coatings that have been equipped with a dry-film preservative. In a similar way, the functionality of a material may be enhanced by the presence of a biocide. For example, by treating the textile from which a tent is manufactured, it can be packed and stored after use even if still damp without the risk of the development of mildew. In other examples, new properties are added through the addition of biocidal active substances, creating surfaces with enhanced hygienic properties etc.

\subsection{The Risk Benefit Equation}

The choice of biocide will depend on its compatibility with the material to be treated and the processes involved in the manufacture of the material and the final article. Which biocide to choose and at which concentration will also depend on the scale, speed and type of effect required to achieve the envisaged benefit. The demonstration of it in a manner that simulates at least some of the range of end-uses and final treated articles is important. This demonstration is necessary to make risk vs. benefit assessments of biocidal active substances and products.

The end use and performance required affect not just the concentration of active substance(s), but also the way they interact with their surroundings (emissions to the environment, skin, food, the possibility of resistance being developed to an active substance or, more significantly, cross resistance with active substances used for clinical purposes etc.) and are important for judging the risk vs. benefit balance. A vital set of questions is therefore what type of activity is required and how much and for how long? One of the purposes of this document is to help identify what that 
data should look like and how it should be generated.

\subsection{The Difficulty with Setting Performance Criteria}

With certain biocidal products such as disinfectants, there are many national and Europe-wide performance criteria that are employed to determine how effective a product needs to be under a certain set of conditions. The approach is based heavily on suspension tests and the performance in practice may differ from that shown in such tests. For example, disinfectant wipes are often tested for efficacy by expressing the liquid from them and using that in a suspension test (e.g. containing 8 $\mathrm{ml}$ product plus $1 \mathrm{ml}$ of a soiling agent and $1 \mathrm{ml}$ of a bacterial suspension). Similarly, products applied by trigger spray or by aerosol are often tested in the same way. Even when they are then applied to a dried deposit of bacteria on a test plaque (as in EN 13697 - Ref. 3) the volume of product to surface area is dramatically larger than would be employed in practice. Also, the methods do not include the mechanical effects of wiping (and consequent physical removal/re-deposition) or any foaming mechanisms etc. Despite this, there is wide acceptance that, in most cases, the tests provide a useful measure and can be related to expectations in practice. In contrast, for the majority of treated materials, whether the treatment is intended to protect the material/article in service or to introduce hygienic or disinfectant-like properties into it, there is little clear relationship between concentration, performance under a set of test conditions and performance in use. Indeed, the scale of an effect may differ quite dramatically for a material depending on the detail of its formulation, the properties of the active substance(s), the conditions under which it will be deployed and the life-span it is expected to achieve.

As an example, a surface coating equipped with a fungicide to protect the finished film from the growth of moulds (see Figure 1) when used in humid interior environments (e.g. in bathrooms) will probably require a lower level of fungicide than a similar coating used on an external facade, where exposure to rain and UV radiation will have an impact on the retention and stability of some active substances. A biocide with a relatively high solubility in water would likely be capable of providing protection to a coating intended for interior use but would probably be less suited for use outdoors. Even if this were not the case, the concentration required to achieve adequate performance for an exterior application would almost certainly need to be significantly higher than for an interior one. Thus, in even a simple application it would be difficult to set an arbitrary performance criterion no matter what testing regime were employed. 


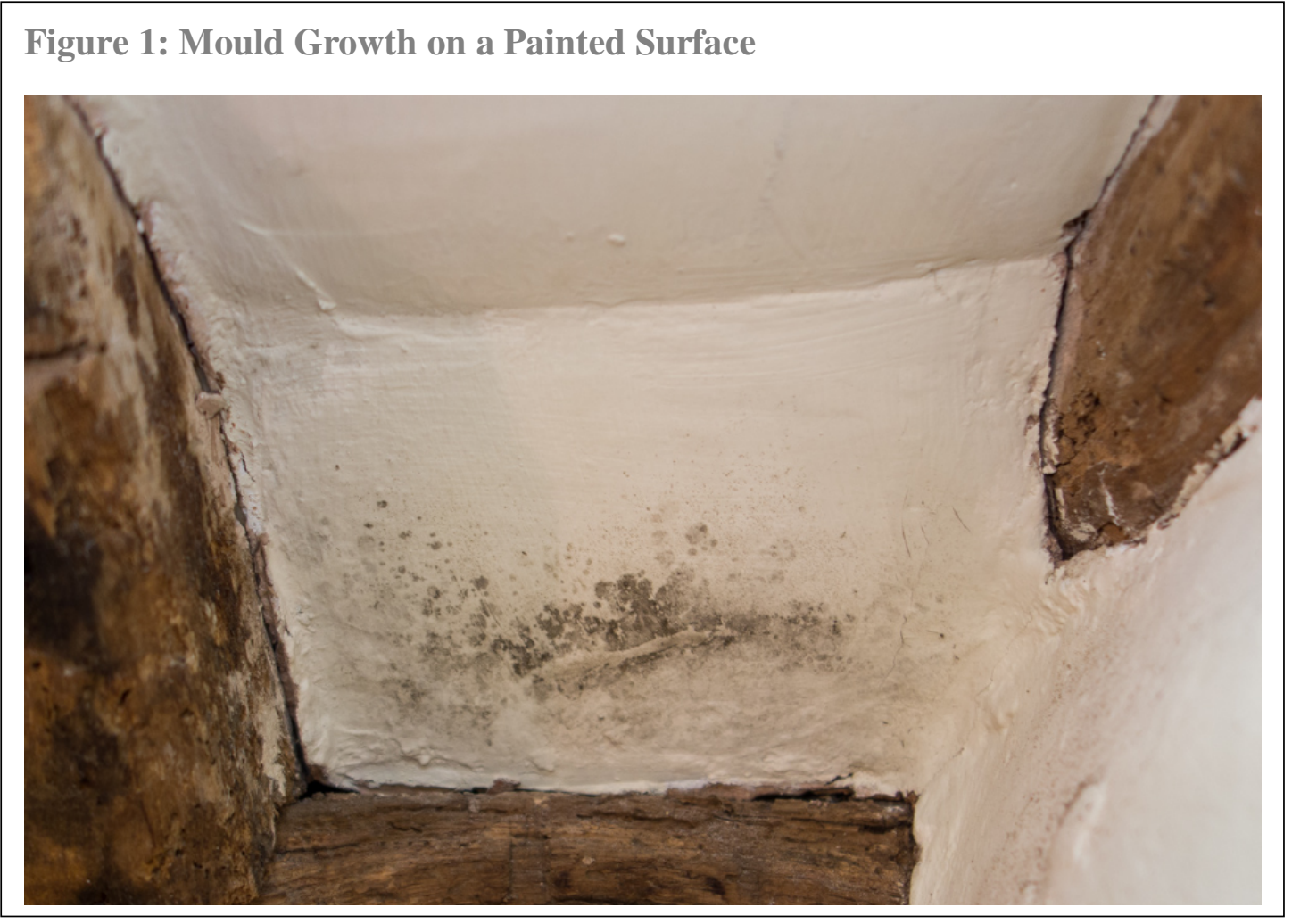

Many plastic formulations are susceptible to growth and spoilage by microorganisms (Ref. 4). For example, fungi can utilise the plasticisers incorporated into certain formulations of polyvinyl chloride (PVC) as a source of nutrients. The depletion that results causes a loss of plasticity and the polymer becomes brittle and cracks as well as becoming visibly fouled by the growth (see Figure 2, which shows both growth as well as partial erosion of the substrate and some physical changes). Polyurethane, for example as used for the soles of shoes, can, through normal use, become colonised by fungi and actinomycetes. The subsequent growth results in discolouration (often a deep purple in colour) and structural failure. The nature of these two polymer systems requires the use of biocidal products with different physical and chemical properties to prevent premature loss of function. These differences in properties have an impact on the suitability of a test method to predict performance. A plastic (e.g. plasticised PVC) equipped with a fungicide with moderate water solubility could be shown to demonstrate fungistatic properties using an agar overlay technique such as described in ISO16869: 2008 (Appendix A). This test relies on sufficient active substance migrating from the plastic into the medium placed over it to inhibit the germination of the fungal spores contained in it. If this occurs it would be expected that the treatment would provide protection to a finished article in service. The use of a campaign of pre-leaching etc. could even be employed to help provide data on anticipated service life. However, another active substance with a much lower solubility in water, may fail to demonstrate activity 
using the same standard. Even though it may provide sufficient protection in practice, it may not produce a sufficiently high enough concentration of active substance in the overlay to inhibit the growth of fungi in the test medium. So not only are performance criteria dependent on the end use conditions, but some testing procedures are more suitable for detecting activity and predicting performance of certain active substances than others. Making comparisons based on one type of test alone can be highly misleading.

In some application areas there is a wide diversity of standard tests available to measure the performance of treated materials whereas in others there are few, if any. With some materials, for example masterbatches ${ }^{1}$ of plastics, the same treated material might be used to manufacture a wide range of products intended for use in a wide range of end applications. The demands on their performance will likely be highly diverse. This makes the task of assessing claims and making judgements about risk vs. benefit even more difficult. The purpose of this document is to provide guidance to this process.

\section{Figure 2: Microbial Growth on a Plasticised PVC Shower Curtain}

\footnotetext{
${ }^{1}$ A masterbatch is a carrier material or plastic additive into which pigments and/or other additives (such as a biocide) have been dispersed. It is often comprised of granules or pellets of the same material as the main plastic into which it will be added at a specified concentration prior to blending and extrusion/moulding
} 


\section{The Role of Biocides in Materials and Articles ${ }^{2}$}

Overview: The purpose of this section is to identify broad sub-divisions in the reasons why biocides are used to treat materials and articles. It describes the division of such uses into either protecting the properties of materials and articles from damage by biological action (i.e. the primary role is protection of materials) or introducing new, often health-associated, properties into a material (i.e. the primary role is protection of humans and livestock).

When biocides are incorporated into materials or used in the production of treated articles they tend to be used with two purposes in mind. They are added either to:

- protect the materials used in the article or the properties of the article in service or,

- to introduce a new property to an article that is not related to the primary function of the article. These claims are usually health-related.

For example, plasticised PVC is protected from damage by fungal growth by the inclusion of a biocide; a suitable service life for an exterior surface coating is ensured through the use of a film-protective biocide formulation. However, a biocide applied to a dish-washing sponge has not been included to protect the material used, but to introduce some sort of self-disinfecting or hygienic property to the article. In some instances this rather broad categorisation may seem to overlap and materials that are protected from damage through microbiological attack are perceived as being more hygienic because they end up, for example, free of mould growth. Of course, one is the consequence of the other but, in this instance, the primary purpose of the biocide is to protect the material. This differentiation is vital to understanding the role of a biocide and the effect it is intended to deliver.

\subsection{The Impact of Claim on Product Type}

The claim being made (or the intent implied) will define in which of the Product Types (PTs) described in Annex V of the Biocidal Products Regulation (BPR) an application will fall. In an example where the primary function of a treatment is to protect a material the application will usually fall under a PT within Main Group 2. However, if the intention of the treatment are effects related to health, this would require that the active substance used was registered within Product Types 1 - 4 of Main Group 1. Claims under PT 18 or 19 of Main Group 3 might be either intended to protect material, e.g. a woollen carpet or health related, e.g. mosquito-repelling

\footnotetext{
2 Whether a treated material falls under the treated articles definition of the BPR is not considered in this document. Though this is important for the question of whether an article has to undergo a national authorization procedure, it is not decisive for the testing of its efficacy.
} 
clothes. Claims related to both types of benefit would require supporting data, but health related claims usually require further justification, evidence and proof. For example, carpets and bedding materials are often treated to inhibit odour and to prevent the growth of moulds. The consequence of this effect might result in a claim that sensitive individuals are less likely to have allergic responses due to the presence of fungal spores. This is sometimes extended to suggest that because mould growth is inhibited, the presence of mites, which feed on the fungi, are reduced and the reduction in frass will reduce further any allergic response. Clearly such claims would require an extensive demonstration that such a sequence of effects does take place under normal conditions of use.

\subsection{Demonstrating that a Biocide is requirred}

Whether a biocide is included in a material/article to either protect it or add new properties to it, a clear benefit should result. It must be possible to demonstrate the reason that the biocide has been incorporated. Any claim made should be both meaningful and realistic. When used to protect a material/article it is important to be able to demonstrate that it would be either damaged, lose essential properties or function or be compromised in terms of durability in service if the biocide were not present. If the biocide has been incorporated to add new, disinfection-like or other health related properties to a material or article, these should be demonstrated to function under the conditions in which it will be used. In the US, focus has been placed on claims that relate to public health; products and articles that do make such claims have to be registered as biocidal products, when certain trigger phrases like antibacterial, biocidal etc. are to be used. Ref. 5). When health claims are omitted, products are extempted form registration. This has resulted in a large number of products being placed onto the market that claim that they contain a biocide to protect the product from microorganisms even though they would be unaffected by them in the first place (e.g. 'this pen has been equipped with a biocide to protect it from bacteria'). The approach may have prevented the use of unsubstantiated claims but has failed to prevent the unnecessary use of biocides, as a demonstration of the benefit of their use has been omitted from the equation. The 'decision tree' in Figure 3 is intended to help identify the nature of the envisaged benefit and, based on that, leads to the right section of this report.

Despite the fact that there will inevitably be some overlaps, a general division has been made in this document. Effects related to the integrity of the material or article or its function are considered in Section 3 and 4. Those that are intended to introduce new properties that are not related to its primary function are considered in Section 5. The purpose is to provide a structure to help understand what benefit is being introduced and how it should be substantiated. 
Figure 3: Flow Diagram to Determine the Nature of the Biocidal Treatment and locate the relevant section in this document.

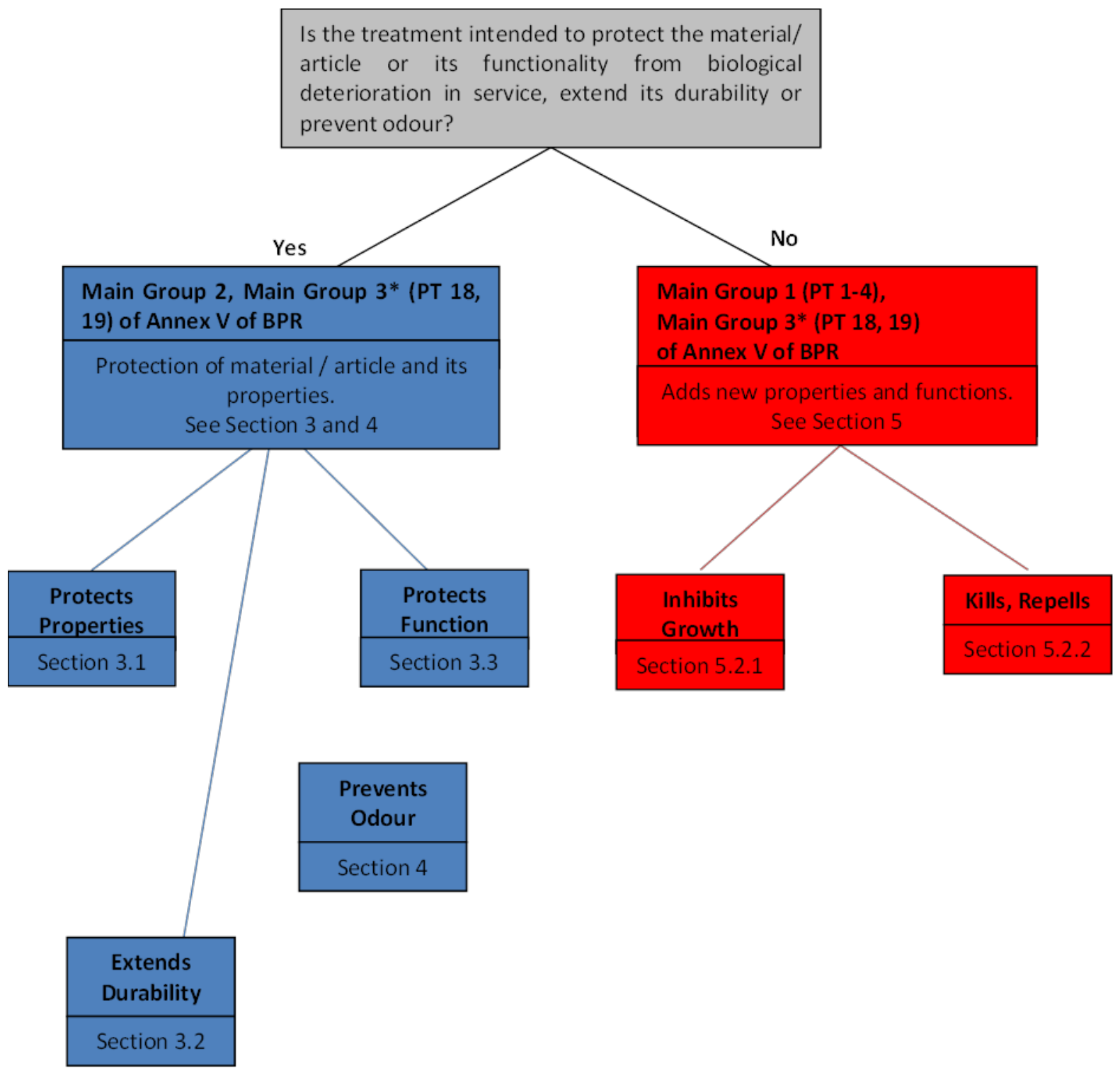

*Insecticides and Repellents can be employed for both purposes, to protect a material and its function, or to introduce new properties, which are not related to the primary function of the article/material. 


\section{Protection of a Material/Article and its Properties}

Overview: The purpose of this section is to examine claims related to the protection of materials and articles and their properties as well as the extension of their service life. It covers mainly those applications that would fall into Main Group 2, Product Types 6, 7, 9 and 10 of Annex V of the BPR. Typical claims associated with these materials and articles include; 'treated to inhibit the growth of mould', 'mould resistant', 'mildew resistant', 'protected from the growth of fungi and algae', etc. Some applications can fall into Main Group 3, Product Types 18 and 19 (Insecticides and Repellents).

The protection of wood (Product Type 8) is, in general, not considered in this document although claims for wood/plastic composites may fall within its scope; for wood-preservatives, specific guidance already exists.

There are many methods capable of describing the effects claimed and, with care, these can be employed to support claims. A selection of the more common methods, sorted by material, is listed in Appendix A.

The function of many biocidal products is obvious and their performance is relatively straightforward to demonstrate. For example, a wet state preservative used in paint and other water-based formulations is intended to protect the product during manufacture and prevent spoilage until the product is used by the consumer. Without such protection the product would quickly become colonised by microorganisms. The metabolism and growth of these would cause undesirable changes to it, such as the development of foul odours, loss of stability (as dispersants and the like are destroyed) and function. The choice of the type of preservative and its concentration etc. is based on technical and commercial considerations, and some form of wet-state challenge test (e.g. Ref. 6) is employed (often along with storage phases) to test the efficacy. The same principle can be applied to other treated materials in which the properties introduced are intended to protect the material, its properties or its function in service.

Although the properties that the inclusion of a biocide in a material/article might introduce may overlap, it is possible to divide the effects they produce into three broad sub-divisions. This process will help in the understanding of the type of demonstration that is required to support the claim for the benefit intended. 


\subsection{Protecting the Properties of a Material}

Many materials are susceptible to damage by organisms. In some instances this damage is readily visible (and it may be that the visual appearance is what needs to be protected). In others it is the mechanical properties of the material that are affected. In many cases a combination of adverse effects are observed. Plastics in which additives have been incorporated to make them highly flexible become brittle when fungi biodegrade the plasticiser. PVC shower curtains are treated with a fungicide to prevent both staining and discolouration and to protect the plasticiser (see Plate 2). As with an in-can preservative, the role of the biocide and the benefit of the treatment is clear and indeed vital to maintaining the properties and function of the treated material. With materials such as PVC, polyurethane, non-synthetic textiles, wood-plastic composites etc. the need for the inclusion of a biocide in the material can be readily demonstrated by studying the behaviour of untreated materials under conditions of normal use or in an accelerated test in the laboratory. The addition of a biocide adds little extra value to the product as it is intended to preserve essential properties of the material/article.

\subsection{Extending Service Life and Durability}

A major application for many biocides is to increase the service life of a material or an article. In many cases, this increase is related to the protection of the actual material itself and is thus an extension of the use described in the section above. Many materials are not susceptible to biological deterioration when freshly manufactured but, upon entering service begin to change (either chemically or physically) and become susceptible. They may also become soiled in service and the presence of soiling may result in colonisation with organisms, the growth of which may cause incidental damage to the material supporting them. Similarly, the aesthetic appearance of a material may be a vital component of its function and the growth of disfiguring organisms would lead to the loss of this function and result in increased maintenance or premature replacement. For example, a house decorated with a facade coating that is equipped with a film fungicide and algicide will not require redecorating due to the presence of fungal and algal growth as frequently as one that is not (see Figure 4). The presence of the biocides extend the durability of the appearance and integrity of the protective film. Powder coatings and coil coatings for rolled sheet metals are sometimes similarly equipped both to preserve their physical appearance (as they cannot be redecorated in situ) and to reduce slip hazards that result from microbiological growth on their surface (e.g. steel ladders and industrial walk-ways). There are clearly economic benefits from the inclusion of the film protection and probably environmental ones (impact of producing more paint etc.) as well as benefits related to function and safety. 


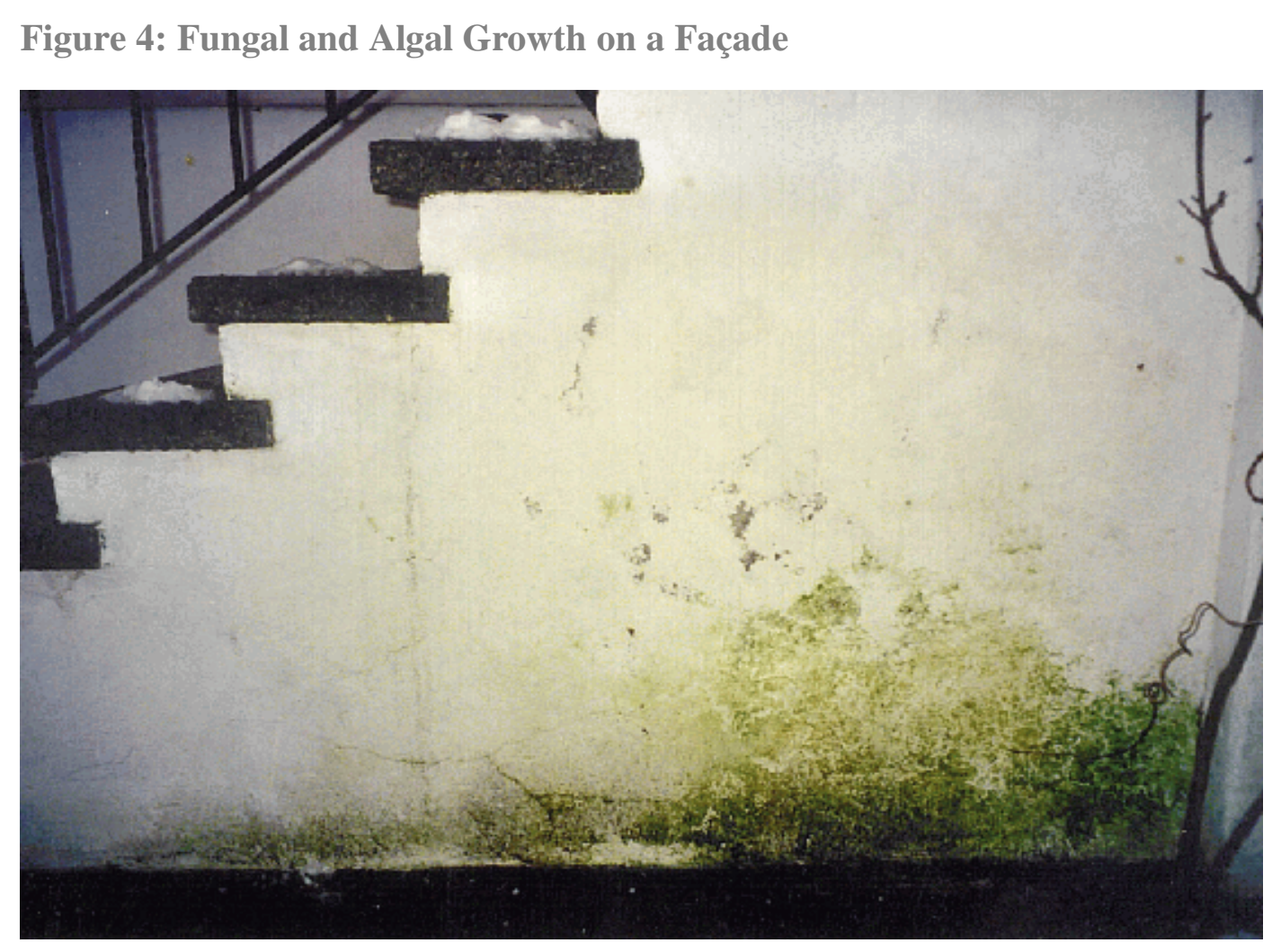

\subsection{Protecting the Function}

In some materials, a biocide may be added to extend its functional properties even where the material itself is not susceptible to biodeterioration under the normal conditions of use. For example, the silicone-based materials used to manufacture insulating sleeves in exterior high-voltage applications are generally unaffected by the growth of microorganisms. Fungal growth may cause staining but rarely results in loss of its functional properties under normal use and changes to the aesthetic properties are not usually a major consideration. However, such sleeves do support the growth of algae on their surface. The presence of this changes moisture retention and affects the insulating properties of the sleeves. This results in arcing and short-circuits leading to interruptions in the supply of electricity. To combat this, biocides with algicidal properties are incorporated into the polymer system. Similarly, biocides can be added to the coating systems used to produce retro-reflective road signs etc., where algal and fungal growth cause changes to their reflective properties, making them harder to see after dark. So, although the materials themselves are not vulnerable to the growth of microorganisms, the final articles or their functions are. Even with these rather indirect applications though, the effect required is well understood and can be observed or measured. It can also be modelled such that the impact of the inclusion of a biocide can be evaluated and a cost-effective addition be determined. 


\subsection{Determining the Level of Performance Required}

Determining the performance of biocides intended to preserve the function and integrity of materials shown in the examples above is a relatively straightforward and intuitive process. There are a number of standard test protocols (see Appendix A) that can be employed for such purposes and the consequences of failure are plain to see and can be measured in both functional as well as commercial terms. Simulating the service life is often achievable and will usually employ a cost - benefit analysis by the end user of the biocide (i.e. the manufacturer of the material/article). In most instances, the choice of biocide and its concentration will be determined by the in-service expectation and the impact on the economics of the material/article. The failure of a treated material or article to live up to the claim made for it will result in the failure of the product in service, leading to complaints (and possibly legal action) up the supply chain and, at the very least, will mean a loss of a repeat sale (if one bought a shower curtain that went mouldy after a few months in service one might complain and expect a replacement or one might simply avoid that brand in the future). The impact of failure would be observed in the market in some form or another.

An essential principle for the claim that a biocide protects a material or article is to show that when it is absent, its properties, functions or durability are compromised. However, although a manufacturer may observe that their product becomes contaminated in practice, it can sometimes be difficult to reproduce this completely under laboratory conditions. This may be due to a lack of suitable test strains and an inability to reproduce the factors that influence the product during manufacture and in use due to the various interactions involved. Therefore, when producing data to be used in support of either active substance approval or product authorisation, it is often necessary to use a model test matrix. This model matrix can be shown to be susceptible to a set of relevant test species rather than a real, final matrix. In this way the effect of the biocide can be demonstrated. The concentrations required in a model matrix will often be lower than those required in practice, as factors such as ageing and decreased stability due to chemical and physical interactions are often not represented in such model systems. The specified shelf-life of true final products can be simulated through appropriate periods of storage, maybe at elevated temperatures or soiling. Thus, through a combination of laboratory-based simulations and knowledge of the requirements of final products, a solution to a range of actual problems can be found. An evaluation of the benefit of a particular biocidal active substance/product is possible. Maximum use rates can be estimated and routes of emission described such that risk vs. benefit can be evaluated.

\subsection{Demonstrating the Need and Measuring the Effect}

One of the most important factors in any risk/benefit analysis is to understand why a 
biocide is required to protect a material or to improve its performance. Thus it is important to use a matrix, even if it is a model one, to show the damage and how the inclusion of the biocide prevents it. There are many methods available worldwide that are used to study the effect of microorganisms (and other biological systems) on materials (a list of some of the more common ones is give in Appendix A). On the whole, biological tests for studying biodeterioration tend to fall into two basic types (simulation tests, see 3.5.1 and laboratory tests, see 3.5.2). Different factors trigger the choice of a test: In some cases the choice of one type of method over another is related to the speed with which it generates results. Often, a method is 'known' to be capable of guiding the choice and concentration of a biocide for a certain material through experience within an industry. Simulation and laboratory tests will be considered separately although it should be noted that one type of method is not necessarily superior to another even when one appears to simulate the end use better than another. In some cases it can be very difficult to demonstrate effects in the laboratory, even in a simulation test, and data from a field trial must be employed. For example, there are few robust methods for assessing the impact of treated materials on the generation of odours in garments and footwear. This is discussed separately below and the role that laboratory data can play in assessing such claims is explored.

\subsubsection{Simulation Tests}

The ideal test method would present a material to a consortium of relevant test organisms under conditions that simulate real life realistically. This would produce effects that are identical to those observed in practice and allow a treatment to be identified with precision. There are methods that come closer to this ideal than others. For example, BS 3900 Part G6 (Appendix A) exposes painted panels that have been inoculated with a mixture of spores of fungi known to colonise paints to humid conditions, free of external nutrients (although these can be added with the inoculum if necessary) for up to 12 weeks (see Figure 5). The resulting growth on untreated coatings has a visual appearance very similar to that observed in practice and pre-exposure, leaching or artificial weathering can be used to help explore service life. A comparison can be made between treated and untreated variants of a formulation. A similar test, that forms the basis of many of the military standards and specifications, is EN 60068-2-10:2005/BS 2011-2.1J: 1989 (see Appendix A), and is applicable to a wider range of materials. Again, samples 
Figure 5: Example of a Simulated Growth Test

\section{BS 3900 Part G6, Method Overview:}

Replicate sub-samples of both treated and untreated variants of each coating are sprayed with a suspension of spores of a range of fungi known to colonise surface coatings. The samples are then transferred to a humid chamber and incubated for up to 12 weeks. The extent of growth is assessed using a rating scale and this, as well as photographs of the panels, are presented as the results.

Rating scale: $0=$ no growth, $1=$ trace to $1 \%$ cover, $2=1-10 \%$ cover, $3=10-30 \%$ cover, $4=$ $30-70 \%$ cover and $5=>70 \%$ cover

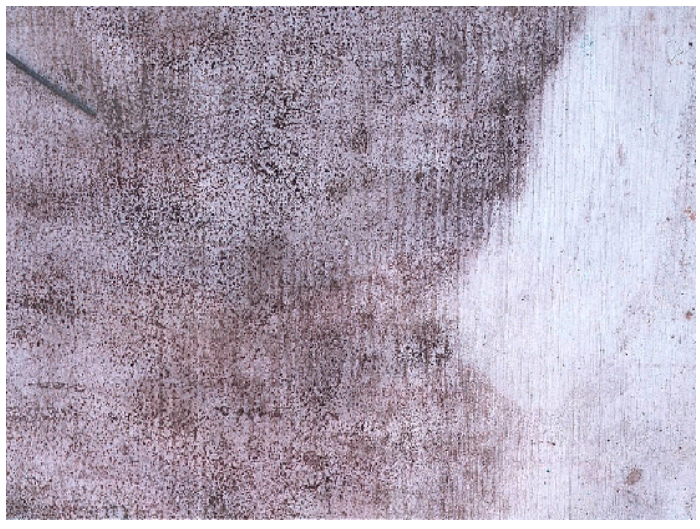

There is no pass/fail criterion in the standard but many workers in the coatings industry consider that growth represented by a rating of 2 is the maximum that would normally be tolerated. An example of growth on an untreated coating is shown on the left.

Example for growth level 5.

are inoculated and incubated under conditions intended to simulate real life or at least be optimal for fungal growth.

Modifications of these methods have been made to allow them to study the effects on algae (the IBRG algal test method for surface coatings) and, less commonly, bacteria.

Laboratory tests on the susceptibility of certain materials to attack by other organisms (e.g. termites) are performed in a similar way. For example, the effectiveness of a termiticide intended to protect a wood - plastic composite (see Figure 6) employed for decking can be performed by exposing treated and untreated variants of materials to sub-colonies of termites either in artificial media or in soil. Similar scenarios can be envisaged for materials such as wool that has been treated against damage by the larvae of clothes

Figure 6: The Effect of the Termite, Coptotermes formosanus on Wood-Plastic Composite Decking Materials

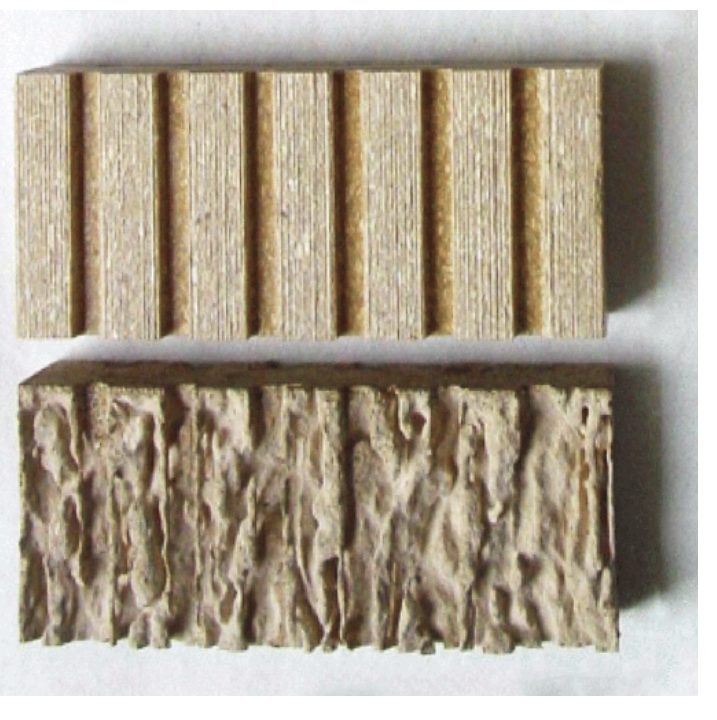


moths and carpet beetles. A slightly less direct approach might be required when assessing repellents though, such as measuring the either frequency or the number of eggs laid on treated and untreated material. However, an end result of less damage should be the final objective.

Effectiveness is assessed in these tests by visual appearance, measuring loss of weight or determining changes in the physical properties of the material (e.g. resistance to bending or extension under load). As with all biological tests, some degree of replication will be essential and tests should employ, as a minimum, three replicate sub-samples of each variant. Care must also be exercised when testing repellents to ensure that the effects observed are sustained. For example, there is evidence that mosquitos adapt to the presence of certain common repellents and so the function of such technology may not have sustained effectiveness, not through loss of active substance, but due to adaptive responses of the target species (Ref. 7).

The above methods are indeed very useful and provide valuable information especially for specific material/biocide combinations and can be correlated in some cases to service expectations. However, they can take a long time to perform and, in many cases, need to be adapted in some manner to accommodate a specific material.

\subsubsection{Laboratory Tests Based on Artificial Growth Media}

By far the most commonly used methods for studying the performance of biocides intended to protect materials are those based on artificial growth media such as agar plates. For example, both ISO 846: 1997 and ASTM G21-09 are used widely in the plastics industry to measure the performance of fungicides in formulations (also ISO 16869: 2008, although its adoption has been relatively slow to date). ISO 846 allows for studies into the susceptibility of plastic formulations to fungal and bacterial deterioration by attempting to make the plastic the sole source of nutrients for the organisms used, as well as providing a variant that provides an external source. Although this standard does little to mimic real-life conditions it can demonstrate whether a material is susceptible to microbiological deterioration or not and whether a biocide can prevent such biodeterioration (provided an untreated variant is included). It also includes a simulation test variant in which samples are buried in soil and then examined for loss of weight and strength (extremely useful in industries manufacturing pipes and cables). 


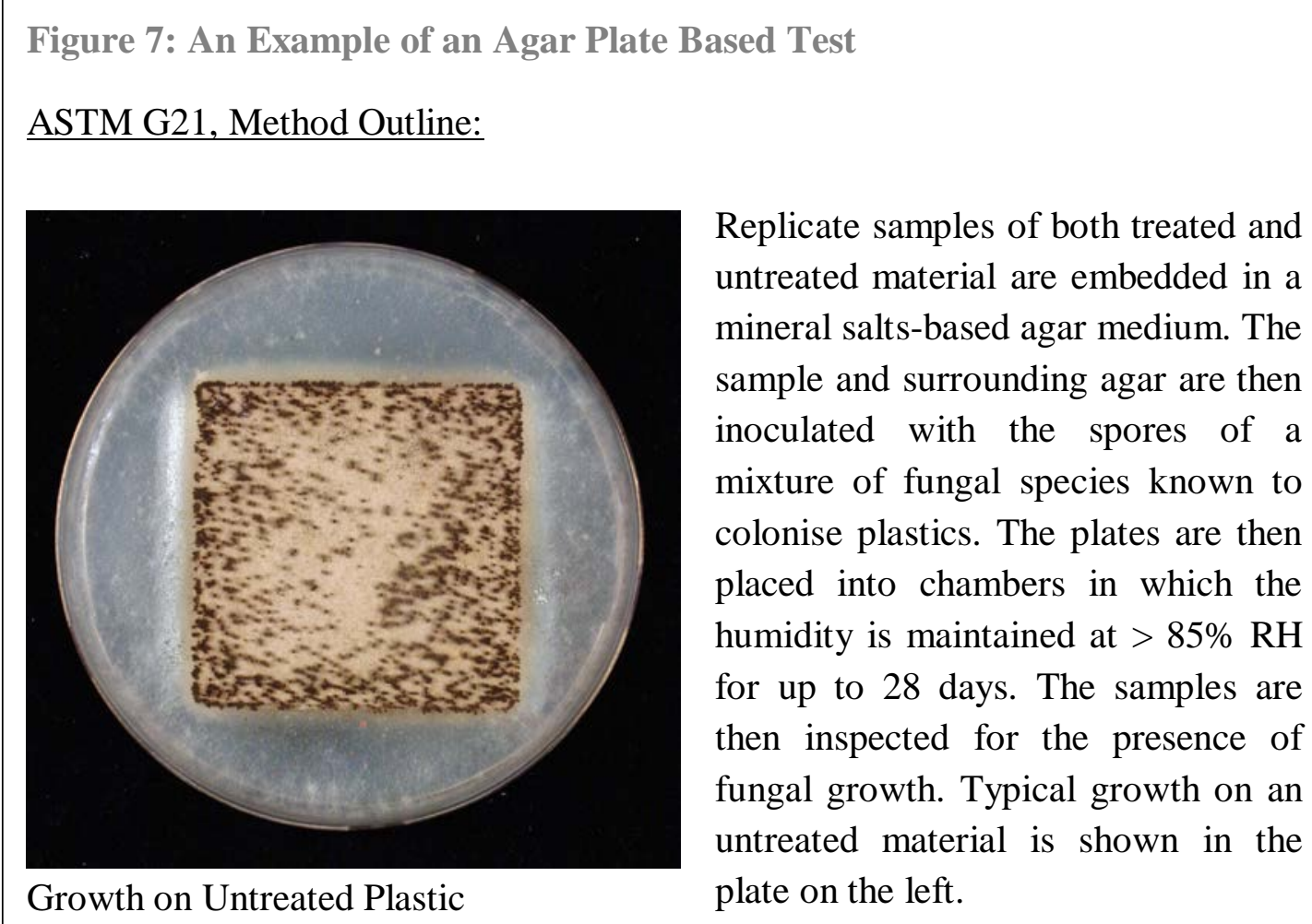

Although making the plastic the sole source of nutrients might seem like the ideal way to examine the ability of a biocide to protect the material, in many instances it is the presence of soiling that leads to colonisation and subsequent damage to the polymer (sometimes referred to as bio-corrosion). Thus, for certain polymers, the presence of external nutrients is an essential prerequisite in determining the efficacy of a biocide in protecting it. In many instances a consortium of organisms is required to effect colonisation and deterioration of the material and, in general, methods that employ consortia should be selected. Similar testing technologies as those used for plastics exist for certain textiles, paper and surface coatings. The most common are listed in Appendix A and a description of the basic principles involved is given in Figure 7 using ASTM G21 as an example.

When selecting the appropriate method, consideration must be given to the release mode characteristics of a particular biocide/material combination. Some biocides have a very low solubility in water and hence are emitted at a very low rate from a matrix. This may be sufficient to protect a material that is inherently highly susceptible and which microorganisms may penetrate and colonise. However, if a test (e.g. ISO 16869 - Appendix A) relies on the emission of the biocide from the matrix to measure the effect, it would indicate that such a biocide has no function. Other materials, which are damaged by growth on their surface (especially where soiling is present) due to the production of extracellular enzymes, may fail to be protected by a biocide with such a low emission rate. Thus, the choice of method 
will be highly dependent on the characteristics of the material as well as the biocide.

\subsection{Basic Requirements for a Valid Test - Protection}

Although there is no method that is universally appropriate for all products, even when considering plastics alone, there are some important basic characteristics related to the measurement of activity that need to be taken into consideration. Even if there are many details that vary from case-to-case, there is one basic principle that applies to all: If the purpose of a biocide in a material or article is to prevent changes to it or to extend its durability, then growth on, or changes to, the untreated material due to the organisms being targeted must be demonstrated in the test.

The array of possible material and biocide combinations is vast and phenomena observed in practice cannot always be reproduced in the laboratory, even in a simulation test. A model matrix would be entirely suitable in many circumstances, provided that the same matrix is used for both the untreated and treated variants and that it is relevant to the intended use. For example, plasticised PVC and polyurethane would be useful models for rigid or semi-rigid polymers and a room temperature vulcanised silicone would provide a useful model of a sealant etc. Relevance is the key factor. Thus, if a treatment is intended to protect natural fibres in service then a natural fibre should be employed as the model. When more than one type of material (e.g. plastics, paints and synthetic fibres) can be protected by the biocide then representative matrices that demonstrate the range of protection should be employed. This is especially important when their end use will lead to quite different emission scenarios (e.g. in one application the biocide may provide essential protection of a matrix whereas in another it may increase durability while in yet another it may prevent the development of odours in service - see Section 4). The objective is to demonstrate the benefit that a biocide can bring such that a balance against potential risks can be judged. The species employed in any test should be relevant to the intended benefit (i.e. fungi should be employed to demonstrate activity of a fungicide, fungistat, etc.). Consortia rather than individual species should be employed (although mixing bacteria with fungi, algae etc. should, in general, be avoided). The species employed in the tests should also be relevant to the material under investigation especially where the prevention of the degradation of a material is intended. In many cases the organisms will be specified with the method. Very limited ranges of model organisms should be avoided where possible (e.g. the use of Aspergillus niger as the sole fungus). The test should include replicates (ideally three or more) for both the treated and untreated variants. In many instances the relevance needs to be explained in some way in terms of the effect required in practice and its duration. This may mean the pre-ageing of samples to provide an example of service life prior to testing. 


\section{Box 1: Basic Requirements for a Valid Test Protection}

The following summary provides a guide to the basic requirements for a valid test:

i An untreated variant of the test material must be included and show the pattern of growth/deterioration that the biocide is intended to prevent at the end of the test.

ii The test should employ organisms that are relevant to the material/problem being addressed.

iii Tests that employ a consortium of organisms should be favoured over those that use single species.

iv A minimum of three replicate test pieces of both treated and untreated materials should be employed.

$\mathrm{v}$ The final data should include either some indication of the impact of service conditions on the performance of the treated material/article or data from an ageing

A number of worked examples are shown in Table 1 below.

Table 1: Protection - Example Claims, Problems and Testing Approaches

\begin{tabular}{|l|l|l|l|}
\hline Claim & PT & Example Problem & Example Method \\
\hline \hline $\begin{array}{l}\text { Wet-state preservative } \\
\text { used to prevent spoilage } \\
\text { of paints etc. }\end{array}$ & 6 & $\begin{array}{l}\text { Water-based paint formulations } \\
\text { become contaminated with } \\
\text { bacteria during manufacture and } \\
\text { use. Subsequent growth leads to } \\
\text { the production of foul odours and } \\
\text { destabilisation of the formulation. }\end{array}$ & $\begin{array}{l}\text { A consortium-based, multiple } \\
\text { challenge test should be used } \\
\text { to demonstrate functionality as } \\
\text { a wet-state preservative in a } \\
\text { relevant matrix, e.g. IBRG } \\
\text { in-can test, see Ref. } 6 .\end{array}$ \\
\hline \hline $\begin{array}{l}\text { Fungicide is used to treat } \\
\text { paper goods to prevent } \\
\text { mould growth in service. }\end{array}$ & 7 & $\begin{array}{l}\text { Labels used on wine and beer } \\
\text { bottles become degraded and } \\
\text { stained by fungi and difficult to } \\
\text { read when stored in cellars and } \\
\text { cool stores. }\end{array}$ & $\begin{array}{l}\text { AsTM D 2020-03 } \\
\text { should demonstrate a high } \\
\text { susceptibility to fungal growth } \\
\text { in the test. Treated samples } \\
\text { should be free of growth. }\end{array}$ \\
\hline
\end{tabular}




\begin{tabular}{|l|l|l|l|}
\hline Claim & PT & Example Problem & Example Method \\
\hline \hline $\begin{array}{l}\text { Biocide with fungicidal } \\
\text { and bactericidal } \\
\text { properties is used to } \\
\text { protect PVC sheet } \\
\text { materials from spoilage } \\
\text { and degradation in } \\
\text { service }\end{array}$ & 9 & $\begin{array}{l}\text { PVC sheet flooring used on solid } \\
\text { floors can become colonised by } \\
\text { bacteria and fungi on its under } \\
\text { surface. This causes staining, } \\
\text { cracking and detachment from the } \\
\text { substrate. }\end{array}$ & $\begin{array}{l}\text { ISO 846 Parts A and C. } \\
\text { Samples of untreated material } \\
\text { should support bacterial and } \\
\text { fungal growth. Treated } \\
\text { material should be free of } \\
\text { growth. }\end{array}$ \\
\hline $\begin{array}{l}\text { Fungicide used to treat } \\
\text { cementitious sheet } \\
\text { building materials to } \\
\text { prevent mould growth. }\end{array}$ & 10 & $\begin{array}{l}\text { Calcium silicate wall boards used } \\
\text { in 'dry-wall' construction can } \\
\text { become colonised by fungi. This } \\
\text { can occur due to water ingress but } \\
\text { is especially problematic shortly } \\
\text { after construction when the } \\
\text { building is drying. Growth on } \\
\text { surfaces in wall voids can give } \\
\text { rise to musty odours and the } \\
\text { production of fungal spores can } \\
\text { cause allergic reactions in } \\
\text { sensitive individuals. }\end{array}$ & $\begin{array}{l}\text { BS3900 Part G6. } \\
\text { rating of 5 after incubation. } \\
\text { Treated materials should show } \\
\text { growth with a rating no higher } \\
\text { than 2. }\end{array}$ \\
\hline
\end{tabular}




\section{$4 \quad$ Prevention of Odour ${ }^{3}$}

Overview: The purpose of this section is to examine claims related to the prevention of odour. This can be seen as being related to the protection of the function of a treated material or treated article. It covers mainly those applications that would fall into Main Group 2, Product Type 9 of Annex V of the BPR.

“...This product-type includes biocidal products which antagonise the settlement of micro-organisms on the surface of materials and therefore hamper or prevent the development of odour and/or offer other kinds of benefits."

The control of odour tends to fall into two distinct groups. In the first the odour is caused by growth of microorganisms on a material or article (e.g. surface coatings in bathrooms) or associated with the use of the article (e.g. pipework associated with pools and spas). Usually, odour is a side-effect of microbial growth and will not be produced when microbial growth is inhibited. Specific odour-control claims will usually not be made.

In the second group a material (usually a textile) is treated with a biocide in order to inhibit the biotransformation of human (or animal) bodily emissions into odour compounds. The intention is often to extend the wear period for garments (especially those that cannot be washed easily) and to improve the quality of the 'wearing experience'. Information related to durability (especially the impact of laundering) is vital to making risk - benefit analyses in many cases.

The prevention of odour in garments and shoes cannot be modelled easily. Data from wearing trials and the like must be used to demonstrate benefits, although some laboratory-based tests can be used to provide supporting evidence. Tests which can be employed as supporting evidence are listed in Appendix B.

The growth of microorganisms on materials results not only in mechanical changes to their properties or alterations to their appearance but can generate unpleasant odours. Aside from being unpleasant to live with, these odours can result in the tainting of food, water and other beverages. They may even render, otherwise serviceable, goods unusable. In many instances, preventing the growth of microorganisms that visually alter the appearance of a material or surface will also eliminate any odours associated with it. For example, the growth of moulds on the surface of paints and sealants in humid locations (e.g. a domestic bathroom) will often lead to the production of musty odours. These, and the release of spores from the growth, can even trigger allergic reactions in sensitive individuals. The addition of a biocide to

\footnotetext{
${ }^{3}$ Only products that control odour through inactivation of micro-organisms are considered here. Malodour can be caused by micro-organisms (e.g. musty odours) or by other sources (e.g. smoke). Odour control products that only remove smells without controlling microorganisms, are not falling under the biocides legislation.
} 
the paints and sealants can inhibit such growth (or extend the time for which the material remains free of it) and thus prevent the formation of odour. In many such examples, the odour, while undesirable, is the consequence of the growth on the substrate and is not the primary target of the treatment but an additional benefit. Such effects are common to many materials that become spoiled by the growth of microorganisms such as tents and awnings.

Some spa systems, such as whirlpool baths, can, when used infrequently, start to produce foul odours due to microbial biofilms forming within the pipe-work they contain. Treating these with disinfectants in the same manner as one might a drain is usually the recommended solution, but is often short-lived. Attempts have therefore been made to use polymer systems for the pipes etc. that have been treated with biocides to prevent colonisation and thus prevent the generation of odours and deposits. The cause of the odour is the colonisation of the material and the growth that occurs. The odour is the side-effect and, as with the others, the prevention of the growth that causes it can usually be demonstrated using the techniques described in Sections 3.5.1 and 3.5.2 above.

A series of applications where the production of odour is not necessarily associated with extensive, visible or even measurable microbial growth is in footwear, apparel, certain disposable items (e.g. nappies and incontinence pads) and other textile, fibre and foam-based items such as towels, bedding, mattresses and carpeting.

Although many products make claims related to the prevention of odour, it might be difficult to determine through use (at least within a reasonable time-frame) whether the product delivers the effect promised or not. Thus, a mechanism is required to determine both whether the claims being made can be substantiated and whether the type and amount of treatment used to achieve it is appropriate. Although some instrumental methods have been proposed for measuring various odours, at present they cannot be considered robust and reliable and the only reliable means of determining effects on odour in apparel are those achieved through organoleptic panels and user trials.

Attempts have been made to simply associate the measurement of an anti-odour effect with the inhibition of growth of the microorganisms which cause the odour. This slightly indirect approach is probably acceptable in situations where significant growth of organisms is the cause of the odour such as in the prevention of odour in carpets, mattresses and the like. In these cases the service life and the demands on the biocidal treatment can be predicted and modelled. For example, a biocidal treatment may be applied to the backing of a carpet intended to prevent fungal growth resulting from dampness and condensation. The carpet might be anticipated to be wet-cleaned by machine a certain number of times while in service and so a growth 
inhibition test similar to those described in Sections 3.5.1 and 3.5.2 could be used to determine a sensible minimum concentration of biocide to employ.

\subsection{Control of Odour in Garments}

By far the largest range of treated materials and articles that claim to either prevent or reduce odour are in footwear and apparel, whether worn in intimate contact with the skin or as outer garments. Some of these garments will be subjected to regular laundering (e.g. socks, underwear and sports garments) whereas others will only be cleaned irregularly, if ever (e.g. shoes, ski jackets etc.). Although a plethora of terms may be used to describe the benefit that such treatments bring, ('stays fresh longer' and the like) they are all making a claim related to the prevention of odours, whether foot odour, body odour or mustiness (e.g. resulting from sportswear left in a holdall, towels that remain damp for extended periods of time etc.).

Some manufactures will have performed wearing trials to assess how well odours are suppressed, possibly in association with various cycles of laundering. However, in the majority of cases the prevention of odour is measured indirectly by measuring microbial inhibition. In the majority of applications the prevention of odour being formed in a garment or shoe is achieved by inhibiting microbial metabolism rather than needing to kill a population. In many circumstances, simply reducing the rate of biotransformation of compounds present in human sweat is sufficient to achieve the effect desired. There is a significant risk therefore that applying tests intended for protection of material from degradation will lead to over-treatment. This would lead to an increased exposure of the person wearing it, as well as increased emissions to the environment either during laundering or at the end of its service life.

\subsection{Testing Methods}

With most of the biocidal functions considered in Section 3, test conditions simulate in-use conditions rather well and the effects of microbial growth or activity can be observed quite easily. With the control of odour, this is much harder to achieve in a laboratory test, as odour cannot be measured in a simple manner. Thus, an accurate measure of function can often only be achieved through a field trial.

Work is in progress to produce tests that simulate specific odour production scenarios in the laboratory. An example is the production of iso-valeric acid, one of the dominant compounds associated with foot odour; tests have attempted to measure the capability of a biocidal treatment to inhibit the bioconversion of iso-leucine to iso-valeric acid. However, a robust protocol has not been devised to date. Thus, at present, the methods that are employed indicate the presence of a biocidal treatment rather than predict its performance in service. Moreover, compared to real-life 
Figure 8: An Agar Plate Based Test for Textiles

\section{AATCC 147, Method Outline:}

A series of parallel streaks are transferred from an agar plate onto a fresh plate such that they will decrease in density of growth. The test sample or a series of pieces of yarn are then pressed into the agar and the plate is incubated for 24 hours.

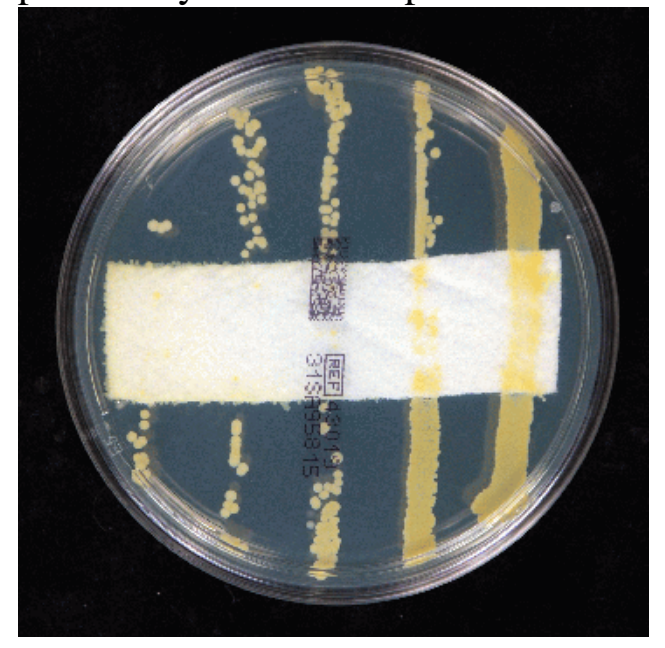

The effectiveness of the treatment is assessed based on whether it prevents growth where the sample comes into contact with it (and whether a zone free of growth is produced) or not. The inhibition of growth of the different densities of streak are used to assess the potency of the treatment. In this example growth is inhibited from the third weakest streak down.

conditions, care must be taken that the test parameters employed do not impose unnecessary demands on the delivery of the biocide. Attempts have been made to correlate the results of such assays with the results of odour trials but this has not proved so far to be a useful general approach, as the results tend to be highly material and biocide related. However, in most cases, as the amount of activity required in practice to inhibit the production of odour is low, these bioassays are useful in measuring the effect of laundering on the loss of activity etc. and thus can at least support the development of products and help ensure that textiles and apparel do not become over-treated.

There are two major types of test that have traditionally been used with textiles (and related materials). The first major group employs agar plates in a similar manner to that described in Section 3.5.2 and the other major group looks at the impact of a treated textile on populations of (usually) bacteria applied to it as a suspension in an aqueous medium. An overview is given in Appendix B.

The agar plate-based tests have almost no useful utility in measuring effects intended to control odour in textiles. Such tests rely on the biocide migrating from the textile into the agar medium at sufficient concentration to inhibit the growth of bacteria either seeded into the agar or placed onto it (see Figure 8). The diffusion characteristics vary hugely from one biocide to another and from one textile to another and the growth medium itself presents a large soiling load to be overcome by the biocide. Larger areas clear of growth are often associated with more potent effects but they could be attributed equally to differences in the leaching rate of a 
biocide from a material. These types of tests do measure inhibition but on a scale usually significantly larger than required to prevent the metabolism associated with the production of odour. They are therefore not recommended.

The second major group, the suspension tests, measure changes in the size of a population following contact with a treated textile. A number of protocols are described in Appendix B. However, most employ relatively high concentrations of nutrients in the suspending medium so that their use, like the agar diffusion methods, can lead to over treatment of textiles. By using lower concentrations of nutrients in the suspending medium and using pre-treatments such as laundering these methods can be adapted for use in measuring effects on odour. Such an adaptation has been applied in the OECD draft Tier 1 method for treated articles (porous materials - Ref. 8) and the IBRG Textile Method (Ref. 9). These are described schematically in Figure 9 and are based on the 'germ' count or absorption phase of ISO 20743: 2007 (Appendix B) where the amount of nutrients present in the cell suspension has been reduced substantially.

Figure 9: Draft OECD/IBRG Tier 1 Textile Test

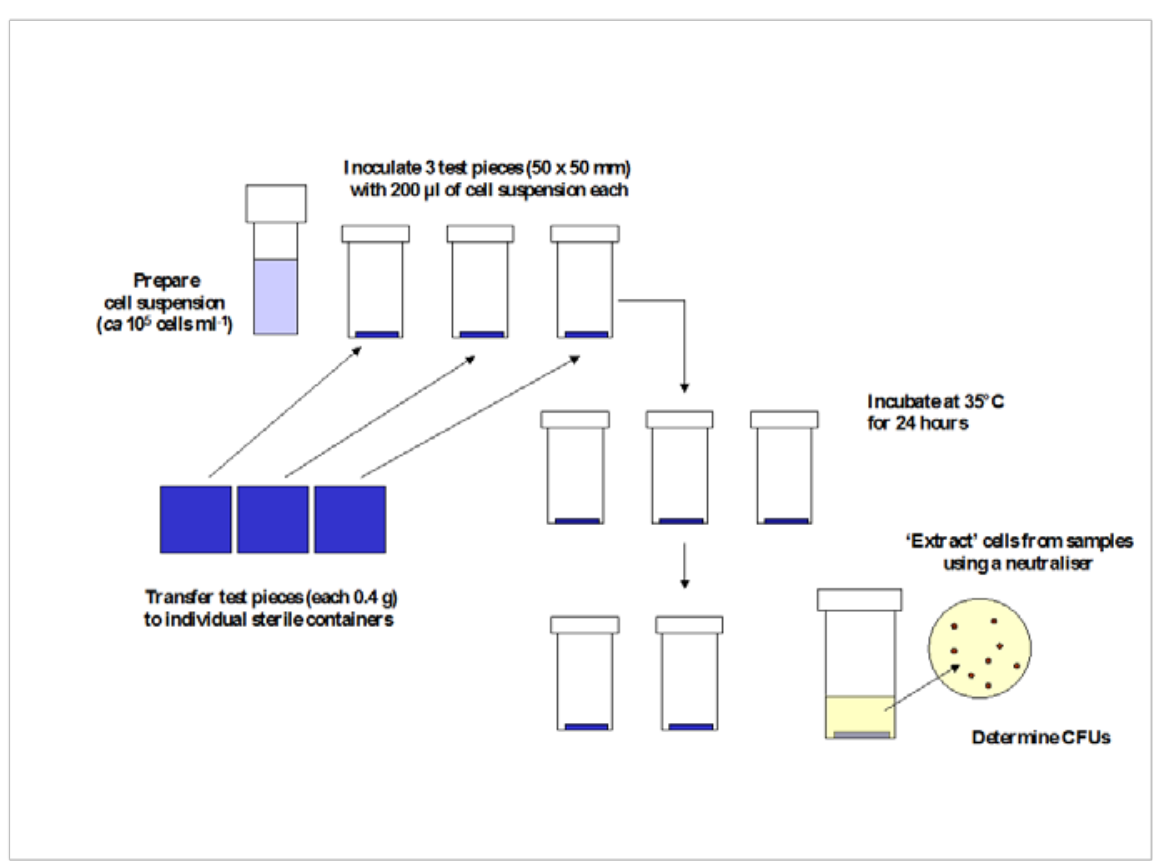

A biocidal treatment on a textile with an appropriate spectrum of activity (e.g. against a range of Gram Positive and Gram Negative bacterial species such as Staphylococcus epidermidis, Corynebacterium xerosis, Proteus vulgaris, Escherichia coli, etc.) would probably inhibit the production of odour. Many such treatments would certainly be capable of producing activity in the suspension tests described above. But unlike 
many other biocidal treatments, the problem is not ensuring that the treatment gives sufficient effect but in ensuring that is does not provide too much. Therefore, tests adapted to textile treatments such as the OECD Draft Tier 1 method and the IBRG Textile method (Figure 9) are preferable.

In general, the effects required to prevent odour in shoes and apparel are subtle. The greatest demand on them is usually in maintaining activity following multiple laundering cycles rather than the demands placed on them in service. The article is not usually intended to deliver a biocide to the skin to prevent odour being formed there. Care must be taken to minimise excess exposure of the skin of the wearer and the environment through emissions of the biocide in use and during cleaning and at the time of disposal.

At present the only truly reliable methods for demonstrating functionality is through replicated and statistically designed wearing trials. The type of bioassay described above can provide useful data related to durability etc. in support of these but care must be taken when interpreting the data they produce. For example, a treatment may be applied to only certain parts of a garment or shoe or it may be present on only a certain number of filaments in the weave of a textile. In the bioassay, the inoculum is dispersed throughout the whole of the sub-sample of textile and any active substance released would be able to migrate throughout that inoculum whereas in use, this may not occur.

In many cases, a large fraction of the active substance incorporated in a textile is lost during laundering, often in the first laundering cycle either through emission of loosely or only partially bound material or associated with loss of fibres (lint). Thus, the emission rate is rarely continuous either to the environment or to the wearer. This also means that there is potential for active substances to be transferred from treated materials to non-treated materials when laundered together. The method described in Figure 9 (as well as chemical analysis) can be useful in measuring the impact of these emission phenomena and for assessing potential cross-transfers. As actual usage would employ a wide range and mix of textile types with a wide variety of anticipated demands and expectations of durability, it would be difficult to address every potential combination and garment type. However, studies on typical textile blends could be used to provide such data to help in the process of assessing risk vs. benefit. Some examples are given in Table 2 below. 
Table 2: Odour: Example Claims, Problems and Testing Approaches

\begin{tabular}{|c|c|c|c|}
\hline Claim & PT & Proof Required & Example Method \\
\hline $\begin{array}{l}\begin{array}{l}\text { Carpet is treated to } \\
\text { prevent } \\
\text { caused by mours } \\
\text { growth. }\end{array}\end{array}$ & 9 & $\begin{array}{l}\text { Data should show that the treated } \\
\text { carpet does not support fungal } \\
\text { growth whereas the untreated one } \\
\text { does. } \\
\text { The effect should be shown to be } \\
\text { sufficiently durable. }\end{array}$ & $\begin{array}{l}\text { A method such as AATCC } 174 \\
\text { can be used to demonstrate } \\
\text { resistance to fungal growth. For } \\
\text { active substances that do not } \\
\text { migrate from the fibres/backing a } \\
\text { cabinet-based simulation test may } \\
\text { be more appropriate. } \\
\text { Activity should be shown to } \\
\text { persist following simulated } \\
\text { ageing. }\end{array}$ \\
\hline $\begin{array}{l}\text { A sports vest is } \\
\text { treated to inhibit the } \\
\text { production of odour. }\end{array}$ & 9 & $\begin{array}{l}\text { Data from a field trial should } \\
\text { show that odour is reduced in } \\
\text { treated sports shirts when } \\
\text { compared with untreated ones. } \\
\text { The effect should be shown to be } \\
\text { of sufficient durability during } \\
\text { service life to match any claim } \\
\text { made. }\end{array}$ & $\begin{array}{l}\text { Wearing trial or scientifically } \\
\text { valid odour based simulation } \\
\text { study. } \\
\text { A comparison of the effectiveness } \\
\text { both before and after simulated } \\
\text { ageing/washing should be } \\
\text { performed. This could be } \\
\text { performed either through field } \\
\text { trials, simulation tests or the use } \\
\text { of a test such as the OECD Tier } 1 \\
\text { method. The latter could be } \\
\text { used to demonstrate that } \\
\text { sufficient activity is still present } \\
\text { after washing/ageing to elicit an } \\
\text { antimicrobial effect. }\end{array}$ \\
\hline
\end{tabular}




\section{$5 \quad$ Materials and Articles Treated to Add New Properties and Functions not Related to the Primary Use}

Overview: The purpose of this section is to examine claims related to the introduction of new, predominantly hygiene-related, claims. It also addresses materials treated with repellents and insecticides against target organisms that have no impact on the material/articles themselves but which are intended to protect the wearer (e.g. clothing equipped with a mosquito repellent or insecticide). It covers mainly those applications that would fall within both Main Group 1, Product Types 1 - 4 and Main Group 3, Product Types 18 and 19 of Annex V of the BPR. Typical claims associated with these materials and articles include; 'anti-bacterial', 'hygienically clean', 'free of bacteria', 'prevents the spread of hazardous bacteria', 'insect-repellent' etc.

Although a large number of basic efficacy tests exist, none are suitable in supporting such claims; in fact, tailored approaches and adaptations must be employed. In the majority of instances the claim made for the final article will be the one that will require demonstration.

In Sections 3 and 4, the benefit of the use of the biocide is clear and can often be measured in a manner that reflects its purpose, even though in the case of odour control reliance must be made of data generated through in-use trials. However, the case is less obvious for treated articles and materials in which a biocide has been incorporated to add new properties that are not related to the primary function of the article or material in question. This includes such effects as hygienic properties and insect repellency.

\subsection{Determining the Purpose of the Treatment}

The very act of including a biocide and introducing antimicrobial properties is often perceived as being desirable, but it is rare that data demonstrating the benefit is presented. The effects envisaged often respond to perceived or hypothetical hazards rather than ones that have been identified and quantified. In some cases performance against a standard may have been shown but the relevance in practice is rarely demonstrated.

There are no internationally accepted criteria by which performance can be judged nor, in many cases, are there accepted limits for the number and types of microorganisms that should be present on surfaces and materials in general. It is therefore very difficult to assess likely benefits from such data.

Of all claims made for antimicrobial effects for treated materials and articles, those made for hygienic effects and benefits are probably the most diverse and also, at 
present, most lacking in the data to support them. Equally diverse is the range of final products that will be manufactured and end uses to which they will be put. Unlike the materials and articles dealt with in Sections 3 and 4, the effects of articles with a hygienic claim cannot be detected by changes in appearance, mechanical properties or odour. The consequences of their failure are not readily apparent and so it is hard for an end-user/purchaser to determine whether the added value they might expect is being delivered. In fact, in many cases, it is even unclear whether there is actually even an issue that the product is supposed to address (e.g. do bacteria on a computer keyboard present an actual hazard?). There is a need for a clear demonstration of whether the effects that the products claim to deliver are substantiated and justified and why they can be expected to bring a benefit (i.e. what is the problem they are addressing?).

To add to this complexity, it is probable that the owner of an active substance will not necessarily be aware of, or be able to anticipate fully, the manner in which it will be employed. In a typical example, an active substance manufacturer will supply a company that will manufacture a range of plastic masterbatches containing it. These will then be marketed to a diverse selection of manufacturers creating articles with a wide range of end uses from household goods to medical disposables and even garments and soft furnishings. Such products will have a wide diversity of end applications and be subject to a wide range of environmental conditions and usage patterns. As a result, they will be required to demonstrate a large array of different antimicrobial effects, at least in scale and speed of action even though the same active substance is present in each. It is often the marketing entity that will provide the support to the final end user and it is these, along with trends and 'innovations' within the various industries, that drive the diversity observed. It is in this way that the claims observed in the market have become so diverse and so disconnected with the effects that may be achievable, although the companies marketing the masterbatches, especially when these are associated with a brand name, apply controls over the claims in an attempt to ensure they can be justified.

The manufacturer of a bedside cabinet for use in hospitals that 'reduces infections' by 'killing bacteria on contact' would be expected to provide data which demonstrates that is exactly what the product does. Usually, the antimicrobial active substance applied has undergone a range of laboratory-based, break-point inhibition tests (see Appendix C), and has been shown to be active against organisms such as Pseudomonas aeruginosa and methicillin resistant Staphyococcus aureus (MRSA). However, this does not provide the evidence required. Even if a masterbatch fortified with the active substance has been incorporated into a matrix, which has been tested and shown to demonstrate activity against Escherichia coli and S. aureus using ISO 22196 (see Figure 10 and Appendix A) this does not mean that the bedside cabinet will fulfil the promised claims. It merely shows that the active substance, 
when incorporated into a matrix and maintained under wet conditions at $35^{\circ} \mathrm{C}$ for 24 hours, can be released and affects bacterial growth/survival in the presence of a low level of nutrients. Neither of these sets of data show how the treated article kills 'bacteria on contact' nor how this effect can reduce infections. What is required is data that shows that microorganisms, when deposited by skin contact (even under simulated conditions) and through fine aerosols, are killed within a time-frame that would prevent the surface becoming a vector for cross contamination. This should be combined with studies on the effect of cleaning and disinfection regimes to show that it is sufficiently durable for the end use.

Similarly, clothes treated with insect repellents should show their effectiveness compared to non-treated clothes, first in a laboratory test, and then in a user trial.

\subsection{Supporting Claims}

As the combination of end use scenarios and claims for articles treated to introduce new properties is so diverse, efficacy needs to be demonstrated on either the individual article or groups of articles with identical claimed functionality. In many cases data on active substance performance and performance of the treated material would need to be supplemented by data specific to the final article, its exposure scenario and the claim being made for it (see Table 3). This would ensure that the conditions of exposure, contact time and target species were appropriate to the end use. It is vital that the benefit that the treated article is intended to deliver be described clearly and that efficacy data demonstrate this benefit. The methods used likely need to be customised to the specific claim but will probably encompass one or more of the groups discussed further below. 
Table 3: Cascade Showing the Various Parties Involved in the Supply Chain for Treated Articles

\begin{tabular}{|c|c|c|}
\hline Party & Data Owned & Example of Efficacy Data Provided \\
\hline Active Substance producer/agent & $\begin{array}{l}\text { Toxicity and ecotoxicity data etc. Basic efficacy data on active } \\
\text { substance (spectrum of activity etc.) and for typical examples in } \\
\text { Product Types in which the active substance will be employed. }\end{array}$ & $\begin{array}{l}\text { Demonstration of basic antibacterial properties } \\
\text { delivered when the active substance is incorporated } \\
\text { into a model matrix. For example a paint, a plastic, a } \\
\text { textile, a ceramic glaze etc. This could be provided by } \\
\text { ISO 22196, ISO 20743, OECD Tier } 1 .\end{array}$ \\
\hline $\begin{array}{l}\text { Marketing Entity/Supplier of a } \\
\text { Masterbatch, etc. }\end{array}$ & $\begin{array}{l}\text { Provider of scientifically valid data to substantiate major claims in } \\
\text { major matrices. Has relationship with Active Substance producer(s) } \\
\text { granting letters of access for toxicity and ecotoxicity data etc. This } \\
\text { provides a commercial relationship with the parties. It is a positive } \\
\text { advantage for them to be able to provide a good supporting package } \\
\text { to their customers }\end{array}$ & $\begin{array}{l}\text { Demonstration of 'real-life' claims. For example, } \\
\text { simulated splash, skin contact, dry contact etc. A range } \\
\text { of example materials would be used (a number of } \\
\text { common polymers, ceramic glazes, various textiles). } \\
\text { Some simple ageing data would be provided. }\end{array}$ \\
\hline Treated Article manufacturer & $\begin{array}{l}\text { Provider of any specific additional data required to substantiate claim. } \\
\text { Has relationship with Marketing Entity or Active Substance } \\
\text { producer(s) (if they deal with them directly) granting letters of access } \\
\text { for toxicity and ecotoxicity etc. and major part of claim data (if they } \\
\text { do not own it themselves). This provides a commercial relationship } \\
\text { with the parties. }\end{array}$ & $\begin{array}{l}\text { Demonstration that the activity predicted by the } \\
\text { example tests provided by the marketing entity are still } \\
\text { expressed in the final article (i.e. manufacturing } \\
\text { processes haven’t affected it) - this could be achieved } \\
\text { using a simple test, for example as described in ISO } \\
22196 \text {. Data related to use conditions and service life } \\
\text { expectation would be produced as well as any data on } \\
\text { organisms specific to the end use. } \\
\text { For example, does the biocide still work when used in a } \\
\text { soap dispenser made of injection moulded ABS? A } \\
\text { splash test dataset is used that shows a reduction in } \\
\text { viability in } 1 \text { hour. Additional activity against MRSA } \\
\text { and Listeria is added as the main uses are in hospitals } \\
\text { and chicken processing factories. }\end{array}$ \\
\hline
\end{tabular}




\subsubsection{Effects Intended to Inhibit Growth and Survival}

A common claim is that a treated article prevents the growth or survival of microorganisms, especially bacteria, on it. In many cases specific species are quoted (e.g. MRSA) and often these are ones that are associated with diseases in man and livestock (and occasionally plants). To make this a realistic objective it presupposes that the target microorganism will actually grow or survive on that material or article when it is in service. A paint intended for use in the corridors, wards and operating theatres of a hospital may claim to have been treated to prevent the growth of disease causing bacteria on it, whereas it is more likely to be the absence of sufficient moisture that is the main reason that they are unlikely to grow (Ref. 10). Thus for any claim that a product inhibits growth, it is vital to demonstrate that growth on the material/article in question does occur under its normal conditions of use (not in some artificial laboratory test such as ISO 22196 - Appendix A).

Many microorganisms demonstrate poor levels of survival when exposed to environmental surfaces even when they do not contain a biocide (Ref. 10) and so, as with growth, it will be necessary to have data that demonstrates that the target species (or at least representative surrogates) do indeed survive on the materials and under the conditions in which the articles are intended to be used. Having identified a situation in which microorganisms do grow or survive and present a hazard, data which shows the beneficial effects of the treatment of a material or article needs to be generated.

Under the majority of indoor situations, whether in a domestic, industrial or healthcare environment, most microorganisms will not grow on environmental surfaces due to lack of humidity. Many will remain viable and under some circumstances continue to metabolise. However, where there is sufficient free water, a source of nutrients and an appropriate temperature, growth can occur even if only at a very slow rate. For example, the ducting associated with air handling systems often has areas where condensation accumulates. Microorganisms reaching these areas can colonise the moist surfaces produced, multiply and be re-released into the air in aerosols. In many cases, although the air handling system will be serviced and cleaned, such growth will go unobserved. It is possible to envisage that the ducting could be manufactured from a material in which a biocide has been incorporated or a coating containing one applied. The condensation of moisture on its surface would release the biocide and prevent microbial growth in any liquid deposits formed. In this example, we have a set of conditions that can be defined in which growth could occur. The environmental conditions are known and the constraints on service life can be estimated. There is even a test method that, with appropriate modification, could simulate the application. For example, sub-samples of treated and untreated examples of the material used in the ducting could be tested using a method adapted from ISO 22196 (see Figure 10). It is likely that organic material would be 
deposited along with any microorganisms and so the nutrient system employed in the standard may be suitable to simulate this. However, the temperature employed in the standard would probably be too high and the contact time may be too short to be relevant. For example, it might prove that using a temperature of $20^{\circ} \mathrm{C}$ and a contact time of 48 hours or more is better suited. The use of the cover film would probably make little difference to the relevance of the data but might prove useful depending on the topography of the test pieces. The objective of the test is to show that under conditions similar to those anticipated in practice a population of bacteria does grow in the simulated condensate and that the presence of the treatment prevents that (it would be useful to supplement the standard test strains with Pseudomonas aeruginosa or even Legionella pneumophila). It would be possible to simulate service life by, for example, pre-leaching both treated and untreated samples in water and increasing the levels of both organic and inorganic soiling materials to describe the limitations of the treatment.

Another example where the effectiveness of a treated material might be simulated by an existing method is in the inhibition of growth of Listeria monocytogenes in food production environments. Although food production facilities are cleaned and disinfected on a regular basis (in some cases after each shift of 8 hours), it has been noted that persistent reservoirs of organisms such as $L$. monocytogenes remain. It has been hypothesised that such reservoirs are one of the factors related to the sporadic outbreaks of food poisoning caused by this organism (Ref. 11), especially in cooked and chilled ready meals. It has been considered possible that treated materials may offer a means of eliminating these reservoirs. As with the air handling example given above, it can be envisaged that a modified version of ISO 22196 could be well suited for this purpose as many surfaces remain wet for extended periods after cleaning processes are applied. The standard organisms could be replaced by $L$. monocytogenes, a temperature more suited to the application would be used (e.g. 10 $15^{\circ} \mathrm{C}$ ) and a contact time of $8-12$ hours employed. The effectiveness of the treatment at inhibiting the survival and growth of the organism could thereby be modelled. External ageing of the samples prior to testing in a manner that simulates the pattern employed in practice would need to be used to determine whether the treatment was capable of sustaining effectiveness for the anticipated lifetime of the material. 
Figure 10: A Test for Measuring Basic Antibacterial Properties of Non-Porous Materials

ISO 22196, Method Outline:

An aliquot (usually $400 \mu \mathrm{l}$ ) of a log phase cell suspension of either Escherichia

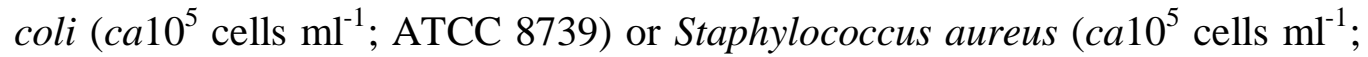
ATCC 6538p) in $1 / 500$ Nutrient Broth are held in intimate contact with each of 3 replicates of both treated and untreated variants of the test materials using a $40 \mathrm{~mm}$ x $40 \mathrm{~mm}$ polyethylene film (e.g. cut from a sterile Stomacher bag) for 24 hours at $35^{\circ} \mathrm{C}$. The populations are then recovered using a neutraliser solution and the size of the surviving populations are determined as colony forming units (CFUs) using a dilution plate count method. Additional replicate unfortified samples are also inoculated in the same manner but are analysed immediately to determine the size of microbial population present prior to incubation. The differences between the initial and final population as well as between the treated and untreated materials are used to assess the basic antibacterial properties of the test materials.

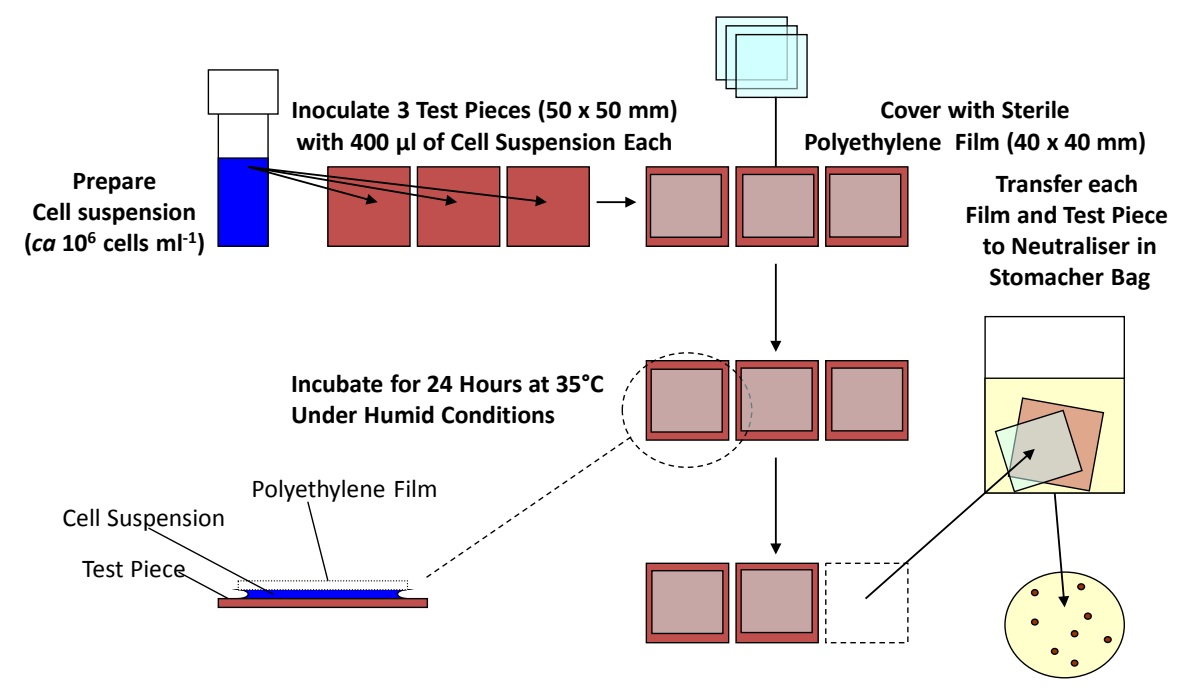

Another scenario for which the use of a modified standard test could be employed is a washing-up sponge that has been treated to inhibit the proliferation and subsequent distribution of potentially harmful microorganisms. A protocol based on the absorption phase of ISO 20743 or the draft Tier 1 method described in Figure 9 could be adapted to simulate the end use. As with the other examples, species, temperature and contact time would need to be changed and information on the impact of ageing on the effect would need to be included, but a model could be devised to describe the functionality of the final article. 
In the above examples, the effect claimed can be linked to a scientifically valid benefit but this may not always be the case. Simply because a claim can be demonstrated does not mean that a benefit will follow automatically. It is therefore vital that the actual benefit that results from the effect claimed be made clear in the submission.

In a related example, $L$. monocytogenes has been shown to grow, albeit slowly, in deposits of food and in condensation on the interior liners of domestic refrigerators (Ref. 12). Studies have been presented that this does not occur on treated liners using an approach similar to that described above. However, it is unlikely that such growth will be a significant factor in the transfer of this organism from one foodstuff to another. There will be more significant routes of transfer (e.g. placing cooked foods onto a shelf previously occupied by uncooked poultry meat). These would need to be taken into consideration when assessing risk vs. benefit.

Clearly there are methods that can be employed to explore the functionality of materials and articles that have been treated to prevent the growth of organisms that pose potential hazards to man and livestock. However, the key to understanding the benefit they may bring, is to be able to show that growth will occur under the normal conditions of use (and possibly storage - e.g. growth of bacteria on the bristles of a toothbrush between uses) and that the treatment can prevent this under those same conditions within a time frame that is relevant to the application. The benefit of the treatment needs to be described clearly such that a valid analysis of risk vs. benefit can be made.

\subsubsection{Applications that Intend to Kill Organisms through Contact}

One of the major aspirations for treated materials and articles that introduce new properties is to kill supposedly harmful organisms. In many instances it is not entirely clear what hazard such organisms might present and, in many cases, evidence that they are present is not even available. Therefore the potential hazard that is being addressed must be defined.

Microorganisms will come into contact with environmental surfaces, textiles and the like through both contact with other materials, foodstuffs, soil and via contact with the skin. They will also be deposited from the air (either by simple, dry settlement or through the deposition of aerosols) as well as through spillages and splashes of liquids etc. or even combinations of these routes. The size and composition of the populations deposited will vary enormously from a few cells per $\mathrm{m}^{2}$ of a single species to hundreds of millions per $\mathrm{cm}^{2}$ or more of a wide range of species depending on the circumstances. In some instances the deposition will be associated with other organic and/or inorganic material, whereas in others little additional material will be 
present. Thus, the potential demand on the function of treated materials is highly varied both in type and scale. This variation will have a profound impact on the ability of a treatment to produce an effect. For example, if a treatment delivers its effect by being emitted from the surface, as will be the case for the majority of active substances, then the emission needs to be triggered somehow. There must be a way for the active substance to interact with the target organism that has come into contact with the material/article. In the majority of cases, water is the crucial component to facilitate such release and transfer. If the event that caused the deposition does not introduce moisture and the normal exposure conditions of the material or article are dry (or only subject to normal, ambient indoor humidity), the ability of a treatment to produce an effect will probably be limited.

The benefit envisaged for treated materials and articles that claim to kill are diverse. They encompass surfaces that are intended to slowly reduce a population over time to those that propose to prevent cross contamination via surfaces that are touched regularly and thus must deliver their effect quickly (e.g. door handles).

As with all of the applications for treated materials and treated articles, the first step to being able to show their benefit is to define the problem that they address. When attempting to eliminate or reduce populations present on surfaces one needs to determine the hazard that their presence implies. For example, are the background populations found on environmental surfaces a cause for concern? In a high dependency ward in a hospital, the presence of bacteria on surfaces that are touched frequently may be of concern but these are less likely to be of consequence in an office or domestic environment. Does the inclusion of antimicrobial properties into an article bring useful functionality to the article or are there other/better practices in place (e.g. regular disinfection of surfaces) to address the hazard?

For example, if a patient in a hospital has severe diarrhoea or vomits over a surface or into bedding, the medical staff will intervene. They will clean the patient, replace bedding and bedclothes etc. and clean and disinfect the areas affected. However, either during the event or during the cleaning-up, it is possible that small deposits, possibly quite remote from the main event (or on the uniforms of the staff), may go unobserved and these could contain large numbers of potentially infective organisms. The presence of a biocide in a material (the release of which might be triggered by the arrival of a deposit of liquid) could help decrease or eliminate these, such that the risk of cross contamination from that deposit is reduced. The effectiveness of this would depend on the rate at which such an effect could be realised (given that the deposit will likely dry fairly quickly) and its ability to function in the presence of additional organic material.

Cross-contamination through surfaces that are touched with a high frequency such as 
door handles present similar issues. The size of the populations deposited by any one individual will likely be low and it will probably be associated with only a small amount of moisture (this may be higher in some situations such at as the exits of washrooms). In addition, the interval between one person touching the handle and the next could be very short. Thus at least two variables (contact time and moisture) must be taken into consideration when designing a protocol intended to demonstrate the effectiveness of the treatment.

Figure 11: Example Test Protocol for Measuring the Activity of Non-Porous Treated Materials on Splashes of Contaminated Liquids

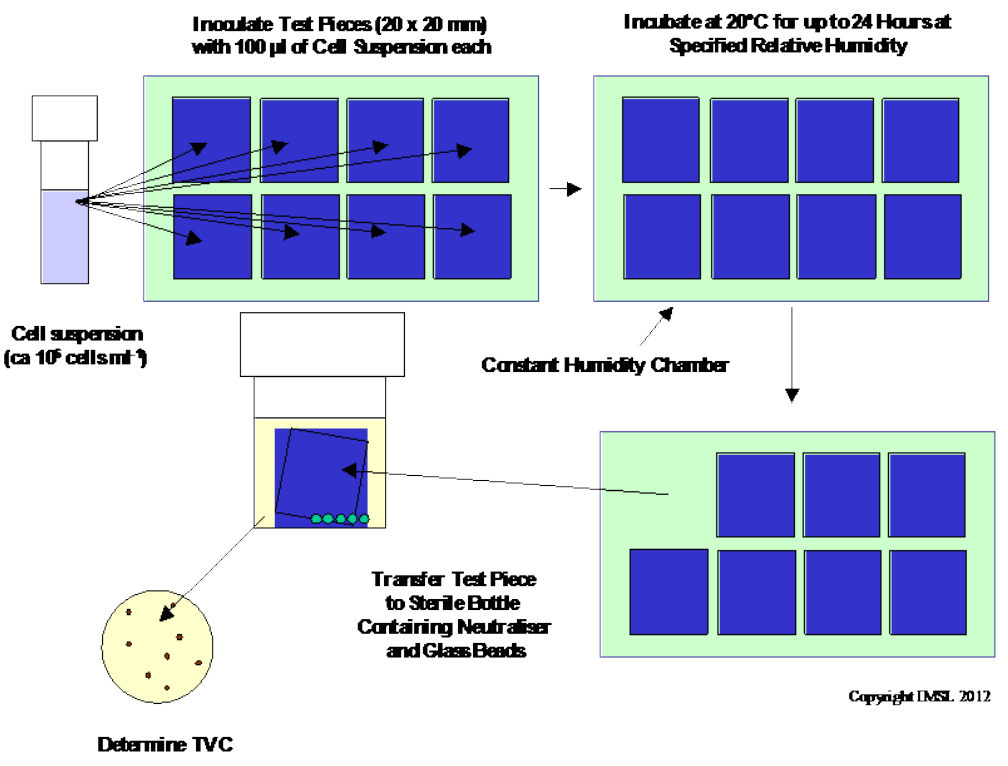

Although the standards that measure the basic antibacterial and antifungal (even antiviral) properties of treated materials can be modified to simulate applications that intend to inhibit growth, none of them provide a methodology that can be adapted for end uses related to the killing ability of non-porous materials. However, ISO 20743 (Appendix B) contains methods that explore the impact of treated textiles on simulated dry contact and these can be adapted for some claimed effects on non-porous materials. There are a number of approaches that have been described in the literature (Ref. 13) and some of these are undergoing further study by the International Biodeterioration Research Group ${ }^{4}$ and have been described, in principle

\footnotetext{
${ }^{4}$ http://www.ibrg.org
} 
at least, by the OECD Task Force on Biocides ${ }^{5}$.

The approach that needs to be taken to validate claims that a treated material or article kills a target population requires that the exposure scenario be understood and that the benefit that is intended is clear and valid. Using the example of contamination by splashes, it is possible to design a test protocol which simulates such an event. In such protocols (see Figures 11 and 12), small droplets of a suspension of bacterial cells (probably in combination with a soiling agent relevant to the end use - e.g. $30 \mathrm{~g}$ litre $^{-1}$ bovine serum albumin) are applied to replicate treated and untreated variants of the material in question (Figure 11 shows the approach used for non-porous materials and Figure 12 shows the approach used for absorbent materials). The samples are then incubated under conditions that replicate the end use of the article and sub-samples are analysed at intervals to determine the number of viable organisms present on them (Total Viable Count - TVC). In this way the method looks at the impact of the treatment on viability over time and the scale and speed of this can be compared with the demands presented by the end use. The size (and number) of the

Figure 12: Example Test Protocol for Measuring the Activity of Porous Treated Materials on Splashes of Contaminated Liquids

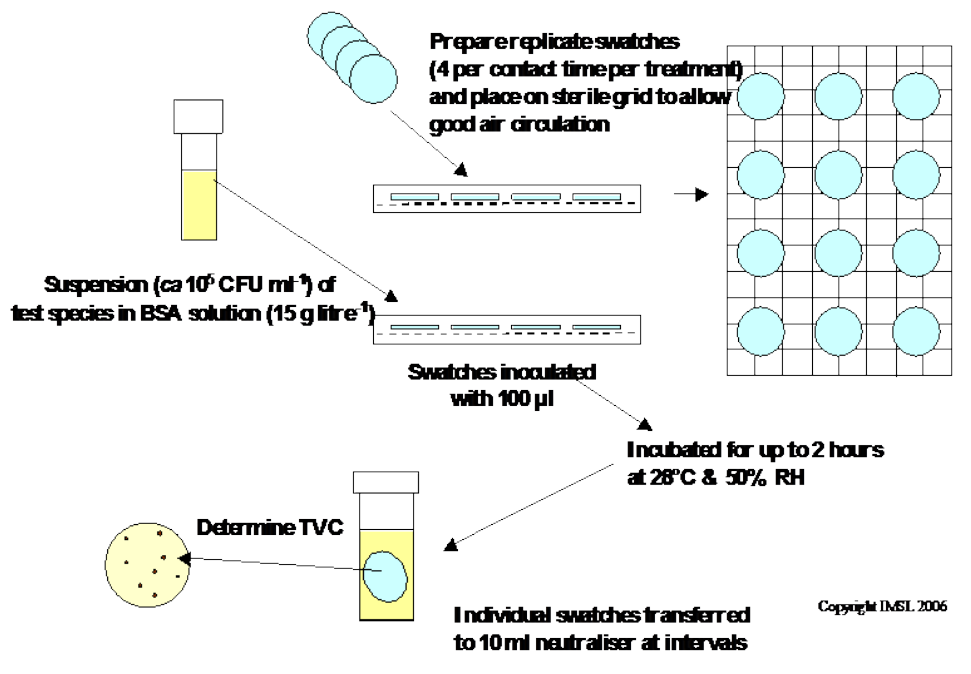

droplets employed along with the temperature, relative humidity and contact time can be adapted to simulate a specific range of events. In this way, a description of the benefit can be produced.

${ }^{5}$ http://www.oecd.org/env/ehs/pesticides-biocides/taskforceonbiocidestfb.htm 
As mentioned above, ISO 20743 (Appendix B) contains methods that are designed to limit the amount of moisture involved in the transfer of microorganisms onto a textile surface to simulate either skin to textile or textile to textile contact. Similar approaches can be described that model the transfer of bacteria from skin to non-porous materials (see Figure 13). By altering contact intervals, test species etc. it is possible in this way to examine the effectiveness of treatments on touch surfaces such as door handles and instrument consoles, keyboards and the like.

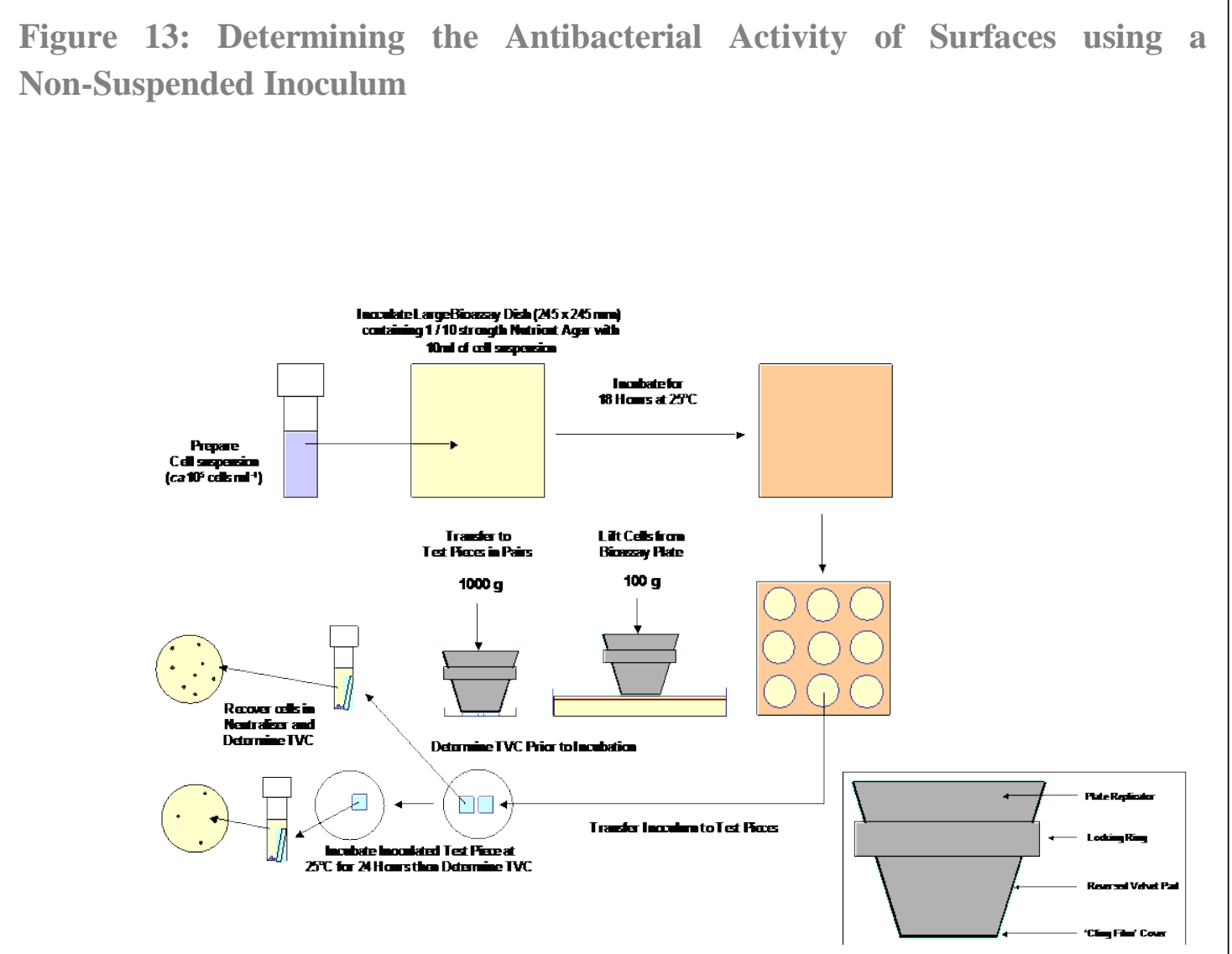

Using methods like those described above and other, scientifically designed, approaches it is possible to simulate in the laboratory the potential effectiveness of treated materials and articles intended to demonstrate killing effects under the normal conditions they will be used in. Similarly, field tests could be performed to determine if, for example, treated surfaces that are touched frequently do have less microorganisms on them than untreated ones. Such trials would require large numbers of replicates and fresh examples of both treated and untreated articles that enter service at the same time. Careful consideration would also need to be given to how the effect is measured. For example, if moist swabs were to be employed it is important that the process of sampling does not affect (promote) the action of the treatment. A neutraliser for the active substance(s) that the article contained would need to be employed to prevent this. Having generated data by either a series of 
relevant simulations and/or field studies, an assessment must then be made as to whether any effects that were observed are sufficiently substantial and of sufficient speed to bring a benefit. Some element of durability testing will almost certainly be required to demonstrate that the benefit is sustained for the intended lifetime of the article.

Effects related to killing activities are not restricted to microorganisms. For example, a textile might be treated with an insecticide with the intention that when biting insects (e.g. Mosquitoes) come into contact with it, they are killed. Laboratory tests may demonstrate that this is indeed the case. However, if the time taken to kill them is not sufficient to stop them from biting the wearer and, if they were a vector of a disease, a possible infection would not have been prevented and the intended functionality would be severely compromised. Speed of action becomes a critical factor in the functionality of the treated article.

\subsection{Basic Requirements for a Valid Test}

As with all treated material and articles, the objective is to demonstrate the benefit that the treatment can bring such that a balance against potential risks can be judged. Efficacy for articles that have been treated to introduce new properties must be performed on the final product. The application area, materials employed, conditions of use and the benefit intended must be simulated realistically by the testing procedures employed. The results must demonstrate that the effect is sufficient to deliver the benefit intended in terms of speed and scale and organisms relevant to the end use must be employed. If specific organisms are the target of the article they must be included. In general, individual species should be employed to describe effects. Tests must demonstrate the durability of the effect for the proposed lifetime that is claimed. If this is shorter than the lifetime of the article, this should be explained. A number of examples are shown in Table 4 below. 
Table 4: Added Properties - Example Claims, Problems and Testing Approaches

\begin{tabular}{|c|c|c|c|}
\hline Claim & PT & Proof Required & Example Method \\
\hline $\begin{array}{l}\text { Bedside cabinet for } \\
\text { use in hospitals that } \\
\text { has been treated to } \\
\text { reduce infections by } \\
\text { killing 'bacteria on } \\
\text { contact'. }\end{array}$ & 2 & $\begin{array}{l}\text { Data should show that } \\
\text { microorganisms, when deposited } \\
\text { through skin contact (even under } \\
\text { simulated conditions) and through } \\
\text { the deposition of fine aerosols are } \\
\text { killed within a time-frame that } \\
\text { would prevent the surfaces } \\
\text { becoming a vector for } \\
\text { cross-contamination. } \\
\text { Skin contact } \\
\text { Aerosol }\end{array}$ & $\begin{array}{l}\text { The method described in Figure } \\
13 \text { is employed to deposit MRSA } \\
\text { onto test plaques. A range of } \\
\text { contact times between } 5 \text { minutes } \\
\text { and } 1 \text { hour are used. A difference } \\
\text { of } 3 \text { orders of magnitude is } \\
\text { suggested to be desirable by } \\
\text { medical personnel. } \\
\text { The method described in Figure } \\
11 \text { is adapted for use by } \\
\text { employing multiple droplets of } 1 \\
\mu l \text { on each test plaque. A range of } \\
\text { contact times between } 5 \text { minutes } \\
\text { and } 1 \text { hour are used to explore } \\
\text { activity. A difference of } 3 \text { orders } \\
\text { of magnitude is suggested to be } \\
\text { desirable by medical personnel. }\end{array}$ \\
\hline $\begin{array}{l}\text { A plastic conveyer } \\
\text { belt is treated to } \\
\text { prevent the survival } \\
\text { and/or growth of } \\
\text { Listeria } \\
\text { monocytogenes } \\
\text { between cleaning } \\
\text { intervals in a food } \\
\text { factory. }\end{array}$ & 4 & $\begin{array}{l}\text { Data should show that } \\
\text { L. monocytogenes grows (or at } \\
\text { least survives) on an untreated } \\
\text { conveyer belt during a } 6 \text { hour } \\
\text { interval. No growth and } \\
\text { significantly reduced survival } \\
\text { should be demonstrated on the } \\
\text { treated belt. }\end{array}$ & $\begin{array}{l}\text { Plaques made of the identical } \\
\text { material used for the belt are } \\
\text { employed in the test. Both } \\
\text { treated and untreated variants are } \\
\text { used. } \\
\text { ISO } 22196 \text { is adapted to simulate } \\
\text { a moist conveyor belt. } \\
\text { L. monocyogenes is used as the } \\
\text { test species and a soiling agent } \\
\text { relevant to the end use is } \\
\text { included. A contact time and } \\
\text { temperature equal to that } \\
\text { encountered in practice are } \\
\text { employed. }\end{array}$ \\
\hline
\end{tabular}




\section{Box 2: Basic Requirements for a Valid Test Added Properties}

The following summary provides a guide to the basic requirements for a valid test:

i. The test should be carried out on the final article.

ii. An untreated variant of the test material must be included such that the impact of the treatment can be demonstrated.

iii. Test conditions should reflect normal conditions of use in terms of humidity, temperature, contact frequency, etc.

iv. The test should employ organisms that are relevant to the end use of the article and the benefit being claimed.

v. Tests that employ a single species of organisms should be favoured over those hat use consortia.

vi. A minimum of three replicate test pieces of both treated and untreated materials should be employed.

vii. The final data should include either some indication of the impact of service conditions on the performance of the treated material/article or data from an ageing study. The intention is to demonstrate how long the claimed benefit will be sustained 


\section{$6 \quad$ References}

1. Selby K, (1966), The Biodeterioration of Cotton Textiles and its Prevention, In Microbiological Deterioration in the Tropics, SCL Monograph No 23.

2. Pantke M, (1977), Test Methods for the Evaluation of Susceptibility of Plasticised PVC and its Components to Microbial Attack, In Biodeterioration Investigation Techniques, Ed Walters AH, Applied Science Publishers, London

3. BS EN 13697:2001 Chemical disinfectants and antiseptics. Quantitative non-porous surface test for the evaluation of bactericidal and/or fungicidal activity of chemical disinfectants used in food, industrial, domestic and institutional areas. Test method and requirements without mechanical action (phase 2/step 2)

4. Wessel CJ, (1964), Biodeterioration of Plastics. Soc, Plas Eng. Trans. 4, $\underline{3}, 193$ 207.

5. US EPA Pesticide Registration (PR) Notice 2000 - 1: Applicability of the Treated Articles Exemption to Antimicrobial Pesticides.

6. Lunenburg-Duindam J, Lindner W (2000), In-Can Preservation of Emulsion Paints. European Coatings J, 66.

7. Stanczyk NM, Brookfield JFY, Field LM, Logan JG (2013) Aedesaegypti Mosquitoes Exhibit Decreased Repellency by DEET following Previous Exposure. PLoS ONE 8(2): e54438. doi:10.1371/journal.pone.0054438

8. Anon. (in Preparation by OECD), Quantitative Method for Evaluating Antibacterial Activity of Porous and Non-Porous Antibacterial Treated Articles.

9. Anon (2013), Quantitative Method for Evaluating Bactericidal Activity of Textiles and Porous Materials and Articles. IBRG TEX/13/005.

10. McEldowney, S. and Fletcher, M. (1988). The effect of temperature and relative humidity on the survival of bacteria attached to dry solid surfaces. Letters in Applied Microbiology 7, 83-86.

11. Holah, JT, Bird J, Hall KE (2004). The microbial ecology of high-risk, chilled food factories; evidence for persistent Listeria spp. and Escherichia coli strains. J Applied Microbiol.97, 1, 68 - 77. 
12. Maktabi S, Jamnejad A, Faramarzian K (2013). Contamination of Household Refrigerators by Listeria species in Ahvaz, Iran. Jundishapur J of Microbiol.6, 3, 301-5

13. Askew P D, 2007. Analysis And Assessment of Current Protocols to Develop Harmonised Test Methods And Relevant Performance Standards For The Efficacy Testing of Treated Articles/Treated Materials, ENV/JM/MONO(2007). 


\section{Appendix A: Methods to Measure the Effects of Protecting Material}

\section{Table I: Methods used to Examine the Resistance of Porous Materials to Biodeterioration: Textiles}

\begin{tabular}{|c|c|c|c|}
\hline Reference & Title & Description & Major Principle/Use \\
\hline EN 14119:2003 & $\begin{array}{l}\text { Testing of textiles -Evaluation of the action of } \\
\text { microfungi }\end{array}$ & $\begin{array}{l}\text { The test is designed to determine the susceptibility of textiles to fungal } \\
\text { growth. Assessment is by visual rating and measurement of tensile strength. }\end{array}$ & Agar plate test \\
\hline AATCC 30-2004 & $\begin{array}{l}\text { Antifungal activity, Assessment on textile materials: } \\
\text { mildew and rot resistance of textile materials }\end{array}$ & $\begin{array}{l}\text { The two purposes of the test are to determine the susceptibility of textiles to } \\
\text { microfungi and to evaluate the efficacy of fungicides on textiles. }\end{array}$ & Agar plate test \\
\hline DIN 53931 & $\begin{array}{l}\text { Testing of textiles; determination of resistance of textiles } \\
\text { to mildew; growth test }\end{array}$ & $\begin{array}{l}\text { The test determines the efficacy of treatments for prevention of fungal } \\
\text { growth on/in textiles. It also allows the performance testing of a treatment } \\
\text { after UV irradiation, leaching etc. }\end{array}$ & Agar plate test \\
\hline MIL-STD-810F & $\begin{array}{l}\text { Environmental Engineering considerations and } \\
\text { laboratory tests; Method 508.5 FUNGUS }\end{array}$ & $\begin{array}{l}\text { The purpose of the method is to assess the extent to which a material will } \\
\text { support fungal growth and how performance of that material is affected by } \\
\text { such growth. }\end{array}$ & $\begin{array}{l}\text { Humid chamber test (90 to } \\
\text { 99\% humidity) }\end{array}$ \\
\hline BS $6085: 1992$ & $\begin{array}{l}\text { Determination of the resistance of textiles to microbial } \\
\text { deterioration }\end{array}$ & $\begin{array}{l}\text { The purpose of the method is to assess the extent to which a material will } \\
\text { support fungal/bacterial growth and how performance of the material is } \\
\text { affected by such growth. } \\
\text { Visual Assessment and measurement of tensile strength. }\end{array}$ & $\begin{array}{l}\text { a) soil burial test; } \\
\text { b) agar plate test, } \\
\text { c) humid chamber test }\end{array}$ \\
\hline $\begin{array}{l}\text { EN ISO 11721-1 } \\
(2001)\end{array}$ & $\begin{array}{l}\text { Textiles - Determination of resistance of } \\
\text { cellulose-containing textiles to micro-organisms: Soil } \\
\text { burial test } \\
\text { Part 1: Assessment of rot retarding finishing }\end{array}$ & $\begin{array}{l}\text { The test is designed to determine the susceptibility of cellulose containing } \\
\text { textiles against deterioration by soil micro-organisms. Preserved and } \\
\text { unpreserved textiles are compared. Visual Assessment and measurement of } \\
\text { tensile strength. }\end{array}$ & Soil burial test \\
\hline $\begin{array}{l}\text { EN ISO 11721-2 } \\
(2003)\end{array}$ & $\begin{array}{l}\text { Textiles - Determination of resistance of } \\
\text { cellulose-containing textiles to micro-organisms: Soil } \\
\text { burial test } \\
\text { Part 2: Identification of long-term resistance of a rot } \\
\text { retardant finish }\end{array}$ & $\begin{array}{l}\text { The test identifies the long-term resistance of a rot-retardant finish against } \\
\text { the attack of soil inhabiting micro-organisms. It allows to make a } \\
\text { distinction between regular long-term resistance and increased long-term } \\
\text { resistance. Visual Assessment and measurement of tensile strength }\end{array}$ & Soil burial test \\
\hline $\begin{array}{l}\text { BS } 2011: \text { Part 2.1J } \\
\text { (IEC 68-2-10) }\end{array}$ & Basic environmental testing procedures & $\begin{array}{l}\text { Mould growth test to show the susceptibility of a material towards } \\
\text { colonization by fungi. }\end{array}$ & $\begin{array}{l}\text { Humid chamber test (90 to } \\
\text { 99\% humidity) }\end{array}$ \\
\hline
\end{tabular}


Table I: Methods used to Examine the Resistance of Porous Materials to Biodeterioration: Textiles

\begin{tabular}{|c|c|c|c|}
\hline Reference & Title & Description & Major Principle \\
\hline AS 1157.2 - 1999 & $\begin{array}{l}\text { Australian Standard - Methods of Testing Materials for } \\
\text { Resistance to Fungal Growth } \\
\text { Part 2: Resistance of Textiles to Fungal Growth. Section } 1 \text { - } \\
\text { Resistance to Surface Mould Growth. }\end{array}$ & $\begin{array}{l}\text { Test specimens are inoculated with a suspension of spores of } \\
\text { Aspergillus niger and then incubated on the surface of a mineral } \\
\text { salts based agar for } 14 \text { days and then assessed for growth. Both } \\
\text { leached and unleached specimens are examined. Glass rings are } \\
\text { employed to hold the specimens in intimate contact with agar when } \\
\text { necessary. Specimens are examined for the presence of surface } \\
\text { mould growth. }\end{array}$ & Agar plate test \\
\hline AS 1157.4 - 1999 & $\begin{array}{l}\text { Australian Standard - Methods of Testing Materials for } \\
\text { Resistance to Fungal Growth } \\
\text { Part 2: Resistance of Textiles to Fungal Growth. Section } 2 \text { - } \\
\text { Resistance to Cellulolytic Fungi. }\end{array}$ & $\begin{array}{l}\text { Test specimens are inoculated with a suspension of spores of } \\
\text { Chaetomium globosum and then incubated on the surface of a } \\
\text { mineral salts based agar for } 14 \text { days and then assessed for growth. } \\
\text { Both leached and unleached specimens are examined and exposed } \\
\text { samples are subjected to a tensile strength test. Glass rings are } \\
\text { employed to hold the specimens in intimate contact with agar when } \\
\text { necessary. }\end{array}$ & Agar plate test \\
\hline AS 1157.3 - 1999 & $\begin{array}{l}\text { Australian Standard - Methods of Testing Materials for } \\
\text { Resistance to Fungal Growth } \\
\text { Part 2: Resistance of Cordage and Yarns to Fungal Growth. }\end{array}$ & $\begin{array}{l}\text { Test specimens are inoculated with a suspension of spores of } \\
\text { Chaetomium globosum and then incubated on the surface of a } \\
\text { mineral salts based agar for } 14 \text { days and then assessed for growth. } \\
\text { Both leached and unleached specimens are examined and exposed } \\
\text { samples are subjected to a tensile strength test. }\end{array}$ & $\begin{array}{l}\text { Agar plate test (other vessels } \\
\text { containing media are } \\
\text { employed for large } \\
\text { specimens). }\end{array}$ \\
\hline
\end{tabular}

Table II: Methods used to Examine the Resistance to Biodeterioration: Geotextiles

\begin{tabular}{|c|c|c|c|}
\hline Reference & Title & Description & Major Principle \\
\hline EN 12225:2000 & $\begin{array}{l}\text { Geotextiles and Geotextiles-related products - Method for } \\
\text { determining the microbiological resistance by a soil burial test }\end{array}$ & $\begin{array}{l}\text { The test is designed to determine the susceptibility of geotextiles } \\
\text { and related products to deterioration by soil micro-organisms. } \\
\text { Visual Assessment and measurement of tensile strength. }\end{array}$ & Soil burial test \\
\hline
\end{tabular}


Table III: Methods used to Examine the Antimicrobial Activity and Microbial Resistance of Paper etc.

\begin{tabular}{|c|c|c|c|}
\hline Reference & Title & Description & Major Principle \\
\hline DIN EN 1104 - 05 & $\begin{array}{l}\text { Paper and board intended to come into contact with foodstuffs } \\
\text { Determination of transfer of antimicrobic constituents }\end{array}$ & $\begin{array}{l}\text { A minimum of } 20 \text { replicate sub-samples (each } 10-15 \mathrm{~mm} \text { in } \\
\text { diameter) taken from } 10 \text { samples of a batch of paper are placed in } \\
\text { intimate contact with nutrient agar plates inoculated with either } \\
\text { Bacillus subtilis or Aspergillus niger and incubated at } 30^{\circ} \mathrm{C} \text { for } 7 \\
\text { days and at } 25^{\circ} \mathrm{C} \text { for } 8 \text { - } 10 \text { days respectively. }\end{array}$ & Zone Diffusion Assay. \\
\hline ASTM D 2020-03 & $\begin{array}{l}\text { Standard Test Methods for Mildew (Fungus) Resistance of Paper } \\
\text { and Paperboard - Direct Inoculation }\end{array}$ & $\begin{array}{l}\text { Replicate samples (3) are inoculated with a suspension of fungal } \\
\text { spores and then incubated on the surface of a minimal mineral-salts } \\
\text { medium to determine if they support fungal growth. }\end{array}$ & Biodeterioration Test. \\
\hline ASTM D 2020-03 & $\begin{array}{l}\text { Standard Test Methods for Mildew (Fungus) Resistance of Paper } \\
\text { and Paperboard - Soil Burial }\end{array}$ & $\begin{array}{l}\text { Replicate samples (5) are buried in soil for } 14 \text { days and then } \\
\text { examined for the deterioration compared with unburied samples } \\
\text { for both physical deterioration and loss of tensile strength. }\end{array}$ & $\begin{array}{l}\text { Biodeterioration/Biodegredad } \\
\text { ation Test. }\end{array}$ \\
\hline AS 1157.7 - 1999 & $\begin{array}{l}\text { Australian Standard - Methods of Testing Materials for } \\
\text { Resistance to Fungal Growth } \\
\text { Part 6: Resistance of Papers and Paper Products to Fungal } \\
\text { Growth. }\end{array}$ & $\begin{array}{l}\text { Test specimens are placed on the surface of a mineral-salts based } \\
\text { agar and then both the specimen and the agar are inoculated with a } \\
\text { suspension of spores of a range of fungi. They are then incubated } \\
\text { for } 14 \text { days and then assessed for growth. Growth on the } \\
\text { specimen is assessed. }\end{array}$ & Agar plate test \\
\hline AS 1157.5 - 1999 & $\begin{array}{l}\text { Australian Standard - Methods of Testing Materials for } \\
\text { Resistance to Fungal Growth } \\
\text { Part 5: Resistance of Timber to Fungal Growth. }\end{array}$ & $\begin{array}{l}\text { Test specimens are placed on the surface of a mineral salts based } \\
\text { agar and then both the specimen and the agar are inoculated with a } \\
\text { suspension of spores of a range of fungi. They are then incubated } \\
\text { for } 14 \text { days and then assessed for growth. Growth on the specimen } \\
\text { is assessed. }\end{array}$ & Agar plate test \\
\hline AS 1157.6 - 1999 & $\begin{array}{l}\text { Australian Standard - Methods of Testing Materials for } \\
\text { Resistance to Fungal Growth } \\
\text { Part 6: Resistance of Leather and Wet 'Blue’ Hides to Fungal } \\
\text { Growth. }\end{array}$ & $\begin{array}{l}\text { Test specimens are placed on the surface of a mineral salts based } \\
\text { agar and then both the specimen and the agar are inoculated with a } \\
\text { suspension of spores of a range of fungi. They are then incubated } \\
\text { for } 14 \text { days and then assessed for growth. Both leached and } \\
\text { unleached specimens are examined. Growth on specimens is } \\
\text { assessed. Sucrose containing media is employed where true } \\
\text { controls cannot be obtained. }\end{array}$ & Agar plate test \\
\hline
\end{tabular}


Table IV: Methods used to Examine the Resistance to Biodeterioration: Plastics

\begin{tabular}{|c|c|c|c|}
\hline Reference & Title & Description & Major Principle \\
\hline ASTM D 5338 - 92 & $\begin{array}{l}\text { Standard test method for Determining aerobic biodegradation of } \\
\text { plastic materials under controlled composting conditions }\end{array}$ & $\begin{array}{l}\text { Test which measures metabolisation rate of plastic materials in } \\
\text { compost by measuring } \mathrm{CO}_{2} \text { output. }\end{array}$ & Biodegradability test \\
\hline ASTM E 1428 - 99 & $\begin{array}{l}\text { Standard test method for evaluating the performance of } \\
\text { antimicrobials in or on polymeric solids against staining by } \\
\text { Streptoverticillium reticulum (a pink stain organism) }\end{array}$ & $\begin{array}{l}\text { The test shows the susceptibility of solid polymeric materials } \\
\text { towards staining. After incubation the test species are rated } \\
\text { visually. }\end{array}$ & Agar plate test \\
\hline ASTM G 22 - 76 & $\begin{array}{l}\text { Standard practice for determining resistance of plastics to } \\
\text { bacteria }\end{array}$ & $\begin{array}{l}\text { Test designed to determine the effect of bacteria on the properties } \\
\text { of plastics }\end{array}$ & Agar plate test \\
\hline ASTM G 21 - 96 & $\begin{array}{l}\text { Standard practice for determining resistance of synthetic } \\
\text { polymeric materials to fungi }\end{array}$ & $\begin{array}{l}\text { The method is designed to assess the susceptibility of a material to } \\
\text { fungal growth. Rate of growth on the specimen is visually } \\
\text { assessed. }\end{array}$ & Agar plate test \\
\hline ASTM G 29 - 96 & $\begin{array}{l}\text { Standard practice for determining algal resistance of plastic } \\
\text { films }\end{array}$ & $\begin{array}{l}\text { Test to determine the susceptibility of immersed plastic films to } \\
\text { the attachment and proliferation of surface-growing algae. }\end{array}$ & Biofouling test \\
\hline EN 14047:2002 & $\begin{array}{l}\text { Packaging - Determination of the ultimate aerobic } \\
\text { biodegradability of packaging materials in an aequeous medium } \\
\text { - Method by analysis of evolved carbon dioxide }\end{array}$ & $\begin{array}{l}\text { Test which measures metabolisation rate of immersed plastic by } \\
\text { measuring } \mathrm{CO}_{2} \text { output. }\end{array}$ & Biodegradability test \\
\hline EN 14048:2002 & $\begin{array}{l}\text { Packaging - Determination of the ultimate aerobic } \\
\text { biodegradability of packaging materials in an aequeous medium } \\
\text { - Method by measuring the oxygen demand in a closed } \\
\text { respirometer }\end{array}$ & $\begin{array}{l}\text { Test which measures metabolisation rate of immersed plastic by } \\
\text { measuring } \mathrm{O}_{2} \text { output. }\end{array}$ & Biodegradability test \\
\hline ISO 846:1997 & Plastics - Evaluation of the action of microorganisms & $\begin{array}{l}\text { Method for determining the biodeterioration of plastics due to the } \\
\text { action of fungi, bacteria and soil microorganisms. } \\
\text { Petri dish tests are performed with or without additional carbon } \\
\text { source. }\end{array}$ & $\begin{array}{l}\text { Agar plate test; } \\
\text { soil burial test }\end{array}$ \\
\hline $\begin{array}{l}\text { EUROCAE ED-14B/ } \\
\text { RTCA DO 160B }\end{array}$ & $\begin{array}{l}\text { Environmental conditions and test procedures for airborne } \\
\text { equipment; Section 13: Fungus resistance }\end{array}$ & $\begin{array}{l}\text { Mould growth test to show the susceptibility of a material towards } \\
\text { the colonization by fungi. }\end{array}$ & $\begin{array}{l}\text { Humid chamber test ( } 90 \text { to } \\
\text { 99\% humidity) }\end{array}$ \\
\hline
\end{tabular}


Table IV: Methods used to Examine the Resistance to Biodeterioration: Plastics

\begin{tabular}{|c|c|c|c|}
\hline Reference & Title & Description & Major Principle \\
\hline MIL-STD-810F & $\begin{array}{l}\text { Environmental Engineering considerations and laboratory tests; } \\
\text { Method 508.5 FUNGUS }\end{array}$ & $\begin{array}{l}\text { The purpose of the method is to assess the extent to which a } \\
\text { material will support fungal growth and how performance of the } \\
\text { material is affected by such growth. }\end{array}$ & $\begin{array}{l}\text { Humid chamber test (90 to } \\
\text { 99\% humidity) }\end{array}$ \\
\hline $\begin{array}{l}\text { BS } 2011: \text { Part } 2.1 \mathrm{~J} \\
\text { (identical with IEC } \\
68-2-10 \text { ) }\end{array}$ & Basic environmental testing procedures & $\begin{array}{l}\text { Mould growth test to show the susceptibility of a material towards } \\
\text { the colonization by fungi. }\end{array}$ & $\begin{array}{l}\text { Humid chamber test (90 to } \\
\text { 99\% humidity) }\end{array}$ \\
\hline ISO 16869:2008 & $\begin{array}{l}\text { Plastics - Assessment of the effectiveness of fungistatic } \\
\text { compounds in plastics formulations }\end{array}$ & $\begin{array}{l}\text { A specimen is placed on a nutrient-salt- agar (without additional } \\
\text { carbon source) in a petri dish and overlayed with the same agar } \\
\text { containing fungal spores. Rate of growth on the specimen is } \\
\text { visually assessed. }\end{array}$ & Agar plate test \\
\hline AS 1157.4 - 1999 & $\begin{array}{l}\text { Australian Standard - Methods of Testing Materials for } \\
\text { Resistance to Fungal Growth } \\
\text { Part 4: Resistance of Coated Fabrics and Electronic Boards to } \\
\text { Fungal Growth. }\end{array}$ & $\begin{array}{l}\text { Test specimens are inoculated with a suspension of spores of } \\
\text { Chaetomium globosum and then incubated on the surface of a } \\
\text { mineral salts based agar for } 14 \text { days and then assessed for growth. } \\
\text { Both leached and unleached specimens are examined and exposed } \\
\text { samples are subjected to a tensile strength test. Glass rings are } \\
\text { employed to hold the specimens in intimate contact with agar when } \\
\text { necessary. }\end{array}$ & Agar plate test \\
\hline AS 1157.11 - 1999 & $\begin{array}{l}\text { Australian Standard - Methods of Testing Materials for } \\
\text { Resistance to Fungal Growth } \\
\text { Part 11: Resistance of Rubbers and Plastics to Surface Fungal } \\
\text { Growth - Section 1: Resistance to Growth }\end{array}$ & $\begin{array}{l}\text { Test specimens are inoculated with a suspension of spores of a } \\
\text { range of fungi and then incubated on the surface of a mineral salts } \\
\text { based agar for } 14 \text { days and then assessed for growth. Both leached } \\
\text { and unleached specimens are examined. Glass rings are employed } \\
\text { to hold the specimens in intimate contact with agar when } \\
\text { necessary. }\end{array}$ & Agar plate test \\
\hline AS 1157.11 - 1999 & $\begin{array}{l}\text { Australian Standard - Methods of Testing Materials for } \\
\text { Resistance to Fungal Growth } \\
\text { Part 11: Resistance of Rubbers and Plastics to Surface Fungal } \\
\text { Growth - Section 2: Fungistatic Properties }\end{array}$ & $\begin{array}{l}\text { Test specimens are placed on the surface of a sucrose, mineral salts } \\
\text { based agar and then both the specimen and the agar are inoculated } \\
\text { with a suspension of spores of a range of fungi. They are then } \\
\text { incubated for } 14 \text { days and then assessed for growth. Both leached } \\
\text { and unleached specimens are examined. Glass rings are employed } \\
\text { to hold the specimens in intimate contact with agar when } \\
\text { necessary. Growth on both the specimen and inhibition of growth } \\
\text { on the surrounding agar are assessed. }\end{array}$ & Agar plate test \\
\hline
\end{tabular}


Table V: Methods used to Examine the Antimicrobial Activity and Microbial Resistance of Surface Coatings \& Adhesives

\begin{tabular}{|c|c|c|c|}
\hline Reference & Title & Description & Major Principle \\
\hline BS3900 Part G6 & "Assessment of resistance to fungal growth & $\begin{array}{l}\text { Replicate test panels coated with the test coating are inoculate with } \\
\text { a suspension of spores of fungi known to grow on the surface of } \\
\text { paints and related materials. The samples are then incubated } \\
\text { under conditions suitable to support fungal growth }\left(23 \pm 2^{\circ} \mathrm{C} \text { and }\right. \\
\text { high humidity/surface condensation). In the published standard, } \\
\text { condensation on the test panels is achieved by increasing the } \\
\text { temperature in a water bath below the samples for short periods of } \\
\text { time. Revisions are in progress which may obviate this step. The } \\
\text { method is validated if fungal growth/germination of spores is } \\
\text { observed after two weeks on a standard coating known to be } \\
\text { susceptible to fungal growth. After incubation growth is rated in } \\
\text { accordance with a scale related to the percent cover with fungal } \\
\text { growth (following visual and microscopical examination). A } \\
\text { natural and artificial soiling are described in the method which can } \\
\text { be employed when appropriate. }\end{array}$ & Biodeterioration Test \\
\hline ASTM D3273-12 & $\begin{array}{l}\text { Standard Test Method for Resistance to Growth of Mold on the } \\
\text { Surface of Interior Coatings in an Environmental Chamber }\end{array}$ & $\begin{array}{l}\text { Replicate test panels coated with the test coating are inoculated } \\
\text { with a suspension of spores of fungi known to grow on the surface } \\
\text { of paints and related materials. The samples are then incubated } \\
\text { under conditions suitable to support fungal growth. }\end{array}$ & Biodeterioration Test \\
\hline WK4201 & $\begin{array}{l}\text { Standard Test Method for Resistance to Mold Growth on } \\
\text { Building Products in an Environmental Chamber }\end{array}$ & $\begin{array}{l}\text { Replicate test panels coated with the test coating are inoculated } \\
\text { with a suspension of spores of fungi known to grow on the surface } \\
\text { of paints and related materials. The samples are then incubated } \\
\text { under conditions suitable to support fungal growth. }\end{array}$ & Biodeterioration Test \\
\hline ASTM D5590-94 & $\begin{array}{l}\text { Standard Test Method for Determining the Resistance of Paint } \\
\text { Films and Related Coatings to Fungal Defacement by } \\
\text { Accelerated Four-Week Agar Plate Assay }\end{array}$ & & Agar Plate Test \\
\hline
\end{tabular}


Table V: Methods used to Examine the Antimicrobial Activity and Microbial Resistance of Surface Coatings \& Adhesives

\begin{tabular}{|c|c|c|c|}
\hline Reference & Title & Description & Major Principle \\
\hline SS345 Appendix B & Formal Title Missing at Present & $\begin{array}{l}\text { The bottom of glass petri dishes are coated with paint. After drying, } \\
\text { a culture of algae in a suitable growth liquid medium is placed into } \\
\text { the dish and incubated under conditions suitable for algal growth. }\end{array}$ & Biodeterioration Test. \\
\hline EN 15457:2007 & $\begin{array}{l}\text { Paints and varnishes - Laboratory method for testing the efficacy } \\
\text { of film preservatives in a coating against fungi }\end{array}$ & $\begin{array}{l}\text { Coatings are applied to glass fibre discs and then placed in intimate } \\
\text { contact with the surface of nutrient agar plates. The coatings and } \\
\text { surrounding media are then inoculated with a mixed suspension of } \\
\text { spores of } 4 \text { fungal species selected from a list of } 10 \text {. The plates are } \\
\text { then incubated at } 24^{\circ} \mathrm{C} \text { for } 21 \text { days and then assessed for growth } \\
\text { using a rating scale. The test is intended to support claims that a } \\
\text { biocide can have an effect in a surface coating in support of its } \\
\text { listing in the relevant use category within the EU BPD. It is not } \\
\text { intended to assess the performance of surface coatings. }\end{array}$ & Zone Diffusion Assay \\
\hline AS 1157.10 - 1999 & $\begin{array}{l}\text { Australian Standard - Methods of Testing Materials for } \\
\text { Resistance to Fungal Growth } \\
\text { Part 10: Resistance of Dried or Cured Adhesives to Fungal } \\
\text { Growth }\end{array}$ & $\begin{array}{l}\text { Test materials coated onto glass microscope slides are inoculated } \\
\text { with a suspension of spores of a range of fungal species and then } \\
\text { incubated on the surface of a mineral salts based agar for } 14 \text { days } \\
\text { and then assessed for growth. }\end{array}$ & Agar plate test \\
\hline EN 15458:2007 & $\begin{array}{l}\text { Paints and varnishes - Laboratory method for testing the efficacy } \\
\text { of film preservatives in a coating against algae }\end{array}$ & $\begin{array}{l}\text { Coatings are applied to glass fibre discs and then placed in intimate } \\
\text { contact with the surface of nutrient agar plates. The coatings and } \\
\text { surrounding media are then inoculated with a mixed suspension of } 3 \\
\text { algal species selected from a list of } 5 \text {. The plates are then incubated } \\
\text { at } 23^{\circ} \mathrm{C} \text { under illumination ( } 16 \text { hour day length, } 1000 \text { Lux) for } 35 \\
\text { days and then assessed for growth using a rating scale. The test is } \\
\text { intended to support claims that a biocide can have an effect in a } \\
\text { surface coating in support of its listing in the relevant use category } \\
\text { within the EU BPD. It is not intended to assess the performance of } \\
\text { surface coatings. }\end{array}$ & Zone Diffusion Assay \\
\hline
\end{tabular}


Table V: Methods used to Examine the Antimicrobial Activity and Microbial Resistance of Surface Coatings \& Adhesives

\begin{tabular}{|c|c|c|c|}
\hline Reference & Title & Description & Major Principle \\
\hline VdL RL06 & $\begin{array}{l}\text { Guideline to Evaluate the Resistance of Coating Materials against } \\
\text { Mold Growth }\end{array}$ & $\begin{array}{l}\text { Coatings are applied to paper discs and then placed in intimate } \\
\text { contact with the surface of nutrient agar plates. The coatings and } \\
\text { surrounding media are then inoculated with a mixed suspension of } \\
\text { spores of } A \text { niger and Penicillium funiculosum. The plates are then } \\
\text { incubated at } 28^{\circ} \mathrm{C} \text { for } 3 \text { weeks and assessed for growth using a rating } \\
\text { scale after } 1,2 \text { and } 3 \text { weeks. Coatings for exterior use and 'wet' } \\
\text { applications are leached in water prior to testing. }\end{array}$ & $\begin{array}{l}\text { Zone Diffusion } \\
\text { Assay/Humid Chamber Test }\end{array}$ \\
\hline VdL RL07 & $\begin{array}{l}\text { Guideline to Evaluate the Resistance of Coating Materials against } \\
\text { Mold Growth }\end{array}$ & $\begin{array}{l}\text { Coatings are applied to paper discs and then placed in intimate } \\
\text { contact with the surface of nutrient agar plates. The coatings and } \\
\text { surrounding media are then inoculated with a mixed suspension of } \\
\text { Scenedesmus vacuolaris and Stichococcus bacillaris. The plates are } \\
\text { then incubated at } 23^{\circ} \mathrm{C} \text { for } 3 \text { weeks under illumination (16 hour day } \\
\text { length, } 1000 \text { Lux) and assessed for growth using a rating scale after } \\
1,2 \text { and } 3 \text { weeks. Coatings for exterior use and 'wet' applications } \\
\text { are leached in water prior to testing. }\end{array}$ & $\begin{array}{l}\text { Zone Diffusion } \\
\text { Assay/Humid Chamber Test }\end{array}$ \\
\hline
\end{tabular}




\section{Appendix B: Methods to Measure Antimicrobial Activity}

Table VI: Methods used to Examine the Antimicrobial Activity of Textiles (fabric, yarn or pile/wadding)

\begin{tabular}{|c|c|c|c|}
\hline Reference & Title & Description & Major Principle \\
\hline "ASTM E2149-10 & $\begin{array}{l}\text { Standard Test Method for Determining the } \\
\text { Antimicrobial Activity of Immobilized } \\
\text { Antimicrobial Agents Under Dynamic } \\
\text { Contact Conditions }\end{array}$ & $\begin{array}{l}\text { Dynamic shake flask test. Test material is suspended in a buffer solution } \\
\text { containing a known number of cells of Klebsiella pneumoniae and agitated. } \\
\text { Efficacy is determined by comparing the size of the population both before and } \\
\text { after a specified contact time. }\end{array}$ & $\begin{array}{l}\text { Relies on either diffusion of } \\
\text { antimicrobial from treated material } \\
\text { into the cell suspension. Some } \\
\text { activity may be due to interaction } \\
\text { between the population and the } \\
\text { surface of the material in suspension } \\
\text { Basic efficacy test that has limited } \\
\text { use as a simulation of final use of a } \\
\text { treated material. }\end{array}$ \\
\hline AATCC 147-2011 & $\begin{array}{l}\text { Antibacterial Activity Assessment of } \\
\text { Textile Materials: } \\
\text { Parallel Streak Method }\end{array}$ & $\begin{array}{l}\text { Agar plates are inoculated with } 5 \text { parallel streaks ( } 60 \mathrm{~mm} \text { long) of either } \\
\text { Staphylococcus aureus or } K \text {. pneumoniae. A textile sample is then placed over } \\
\text { the streaks and in intimate contact with the surface of the agar and incubated. } \\
\text { Activity is assessed based on either the mean zone of inhibition over the } 5 \\
\text { streaks or the absence of growth behind the test specimen. }\end{array}$ & $\begin{array}{l}\text { Zone diffusion assay. } \\
\text { Basic efficacy test that has limited } \\
\text { use as a simulation of final use of a } \\
\text { treated material. }\end{array}$ \\
\hline AATCC 100-2012 & $\begin{array}{l}\text { Antibacterial Finishes on Textile Materials: } \\
\text { Assessment of. }\end{array}$ & $\begin{array}{l}\text { Replicate samples (sufficient to absorb } 1 \mathrm{ml} \text { of test inoculum) of fabric are } \\
\text { inoculated with individual bacterial species (e.g. Staph. aureus and } K \text {. } \\
\text { pneumoniae) suspended in a nutrient medium. The samples are incubated under } \\
\text { humid conditions at } 37^{\circ} \mathrm{C} \text { for a specified contact time. Activity is assessed by } \\
\text { comparing the size of the initial population with that present following } \\
\text { incubation. A neutraliser is employed recovery. }\end{array}$ & $\begin{array}{l}\text { Cell suspension intimate contact test. } \\
\text { Basic efficacy test that has limited } \\
\text { use as a simulation of final use of a } \\
\text { treated material. }\end{array}$ \\
\hline XP G 39-010 & $\begin{array}{l}\text { Propriétés des étoffes - Étoffes et surfaces } \\
\text { polymériques à propriétés } \\
\text { antibactériennes - Caractérisation et mesure } \\
\text { de l'activité antibactérienne }\end{array}$ & $\begin{array}{l}\text { Four replicate samples of test material are placed in contact with an agar plate } \\
\text { that has been inoculated with a specified volume of a known cell suspension of } \\
\text { either Staph. aureus and K. pneumoniae using a } 200 \mathrm{~g} \text { weight for } 1 \text { minute. The } \\
\text { samples are then removed. Duplicate samples are analysed for the number of } \\
\text { viable bacteria both before and after incubation under humid conditions at } 37^{\circ} \mathrm{C} \\
\text { for } 24 \text { hours. A neutraliser is employed during cell recovery. }\end{array}$ & $\begin{array}{l}\text { Cell suspension intimate contact test. } \\
\text { The transfer method of inoculation } \\
\text { could be adapted to provide some } \\
\text { simulation data. }\end{array}$ \\
\hline
\end{tabular}


Table VI: Methods used to Examine the Antimicrobial Activity of Textiles (fabric, yarn or pile/wadding)

\begin{tabular}{|c|c|c|c|}
\hline Reference & Title & Description & Major Principle \\
\hline JIS L 1902: 2008 & $\begin{array}{l}\text { Testing Method for Antibacterial Activity of Textiles } \\
\text { Qualitative Test }\end{array}$ & $\begin{array}{l}\text { Three replicate samples of fabric, yarn or pile/wadding are placed } \\
\text { in intimate contact with the surface of agar plates that have been } \\
\text { inoculated with a cell suspension of either Staph aureus or } \\
\text { K. pneumoniae and incubated at } 37^{\circ} \mathrm{C} \text { for } 24 \text { - } 48 \text { hours. The } \\
\text { presence of and size of any zone of inhibition around the samples is } \\
\text { then recorded. }\end{array}$ & $\begin{array}{l}\text { Zone diffusion assay. } \\
\text { Basic efficacy test that has } \\
\text { limited use as a simulation of } \\
\text { final use of a treated material. }\end{array}$ \\
\hline JIS L 1902: 2008 & $\begin{array}{l}\text { Testing Method for Antibacterial Activity of Textiles } \\
\text { Quantitative Test }\end{array}$ & $\begin{array}{l}\text { Replicate samples of fabric ( } 6 \text { of the control and } 3 \text { of the treated) } \\
\text { are inoculated with individual bacterial species (e.g. Staph. aureus } \\
\text { and K. pneumoniae) suspended in a heavily diluted nutrient } \\
\text { medium. The samples are incubated under humid conditions at } 37^{\circ} \\
\mathrm{C} \text { for a specified contact time. Activity is assessed by comparing } \\
\text { the size of the initial population in the control with that present } \\
\text { following incubation. No neutraliser is employed during cell } \\
\text { recovery. }\end{array}$ & $\begin{array}{l}\text { Cell suspension intimate } \\
\text { contact test. } \\
\text { Basic efficacy test that has } \\
\text { limited use as a simulation of } \\
\text { final use of a treated material. }\end{array}$ \\
\hline EN ISO 20645 - 2004 & $\begin{array}{l}\text { Textile Fabrics - Determination of the antibacterial activity - } \\
\text { Agar plate test (ISO/FDIS 20645:2004) }\end{array}$ & $\begin{array}{l}\text { Four replicate samples of fabric }(25 \pm 5 \mathrm{~mm}) \text { are placed in intimate } \\
\text { contact with a solid nutrient medium in a petri dish. The samples } \\
\text { are then overlaid with molten solid nutrient media which has been } \\
\text { inoculated with a cell suspension of either Staph. aureus, } \\
\text { Escherichia coli or } K \text {. pneumoniae. The plates are then incubated } \\
\text { for between } 18 \text { and } 24 \text { hours and the plates are then assessed for } \\
\text { growth based on either the presence of a zone of inhibition of }>1 \\
\text { mm or the absence/strength of the growth in the media overlaying } \\
\text { the test specimen. }\end{array}$ & $\begin{array}{l}\text { Zone diffusion assay. } \\
\text { Basic efficacy test that has } \\
\text { limited use as a simulation of } \\
\text { final use of a treated material. }\end{array}$ \\
\hline SN 195920 & $\begin{array}{l}\text { Examination of the Antibacterial Effect of Impregnated Textiles } \\
\text { by the Agar Diffusion Method }\end{array}$ & $\begin{array}{l}\text { Four replicate samples of fabric }(25 \pm 5 \mathrm{~mm}) \text { are placed in intimate } \\
\text { contact with a solid nutrient medium in a petri dish. The samples } \\
\text { are then overlaid with molten solid nutrient media which has been } \\
\text { inoculated with a cell suspension of either Staph. aureus or } E \text { coli. } \\
\text { The plates are then incubated for between } 18 \text { and } 24 \text { hours and the } \\
\text { plates are then assessed as described in BS EN ISO } 20645 \text { above. }\end{array}$ & $\begin{array}{l}\text { Zone diffusion assay. } \\
\text { Basic efficacy test that has } \\
\text { limited use as a simulation of } \\
\text { final use of a treated material. }\end{array}$ \\
\hline
\end{tabular}


Table VI: Methods used to Examine the Antimicrobial Activity of Textiles (fabric, yarn or pile/wadding)

\begin{tabular}{|c|c|c|c|}
\hline Reference & Title & Description & Major Principle \\
\hline SN195924 & $\begin{array}{l}\text { Textile Fabrics - Determination of the Antibacterial Activity: } \\
\text { Colony Plate Count Method }\end{array}$ & $\begin{array}{l}\text { Fifteen replicate samples (each replicate is comprised of sufficient } \\
\text { specimens of } 25 \pm 5 \mathrm{~mm} \text { to absorb } 1 \mathrm{ml} \text { of test inoculum) are } \\
\text { inoculated with cells of either } E \text {. coli or Staph. aureus suspended in } \\
\text { a liquid nutrient medium and incubated in sealed bottles for up to } \\
24 \text { hours at } 27^{\circ} \text { C. After } 0,6 \text { and } 24 \text { hours, } 5 \text { replicate samples are } \\
\text { analysed for the size of the viable population present. A neutraliser } \\
\text { is employed. An increase of } 2 \text { orders of magnitude of the } \\
\text { population exposed to a control sample is required to validate the } \\
\text { test. The method defines a textile as antibacterial if no more than } \\
\text { a specified minimum level of growth is observed after } 24 \text { hours in } 4 \\
\text { of the } 5 \text { replicate groups of samples. }\end{array}$ & $\begin{array}{l}\text { Cell suspension intimate } \\
\text { contact test. } \\
\text { Basic efficacy test that has } \\
\text { limited use as a simulation of } \\
\text { final use of a treated material. }\end{array}$ \\
\hline SN195921 & $\begin{array}{l}\text { Textile Fabrics - Determination of Antimycotic Activity: Agar } \\
\text { Diffusion Plate Test }\end{array}$ & $\begin{array}{l}\text { Replicate (4) samples of sterilised fabric ( } 25 \pm 5 \mathrm{~mm} \text { diameter) are } \\
\text { placed in intimate contact with a solid nutrient medium in a petri } \\
\text { dish. Each petri dish has been prepared as a double layer. The first } \\
\text { layer consists of } 10 \mathrm{ml} \text { nutrient agar, the second layer of another } 10 \\
\mathrm{ml}^{-} \text {of the same nutrient agar to which } 0.1 \mathrm{ml} \text { spore suspension }\left(10^{7}\right. \\
\mathrm{ml}^{-1} \text { ) of either Candida albicans, Aspergillus niger, Cladosporium } \\
\text { sphaerospermum or Trichophyton mentagrophytes had been } \\
\text { added. The plates are then incubated at } 28^{\circ} \mathrm{C} \text { either } 2 \text { days (C. } \\
\text { albicans) or } 7 \text { days ( A. niger, C. sphaerospermum and } \\
T \text {. mentagrophytes). The test is valid when control specimens of } \\
\text { the same material without biocide, or of a biocide-free standard } \\
\text { specified cotton material are fully overgrown. Good antimycotic } \\
\text { efficacy is considered to be demonstrated when the specimens } \\
\text { show no fungal growth on their surface. The test specifies that both } \\
\text { sides of a material have to be tested. }\end{array}$ & $\begin{array}{l}\text { Zone diffusion assay. } \\
\text { Basic efficacy test that has } \\
\text { limited use as a simulation of } \\
\text { final use of a treated material. }\end{array}$ \\
\hline
\end{tabular}


Table VI: Methods used to Examine the Antimicrobial Activity of Textiles (fabric, yarn or pile/wadding)

\begin{tabular}{|c|c|c|c|}
\hline Reference & Title & Description & Major Principle \\
\hline ISO 20743 & $\begin{array}{l}\text { Textiles - Determination of antibacterial activity of antibacterial } \\
\text { finished products: Absorption method }\end{array}$ & $\begin{array}{l}\text { Replicate (6) samples of textile are inoculated with a standardised } \\
\text { broth culture of either Staph. aureus or K. pneumoniae in } \\
\text { individual tubes and then incubated at } 37^{\circ} \mathrm{C} \text { for } 18-24 \text { hours in } \\
\text { closed containers. Samples are analysed for the presence of viable } \\
\text { bacteria both before and after incubation by either total viable } \\
\text { count or the determination of total ATP. Samples are sterilised } \\
\text { prior to testing and a neutraliser is employed during recovery. } \\
\text { The test is validated by growth of ^ } 1 \text { order of magnitude during the } \\
\text { incubation period. }\end{array}$ & $\begin{array}{l}\text { Cell suspension intimate } \\
\text { contact test. } \\
\text { Basic efficacy test that has } \\
\text { limited use as a simulation of } \\
\text { final use of a treated material. }\end{array}$ \\
\hline ISO 20743 & $\begin{array}{l}\text { Textiles - Determination of antibacterial activity of antibacterial } \\
\text { finished products: Transfer method }\end{array}$ & $\begin{array}{l}\text { Replicate (6) samples of test material are placed in contact with an } \\
\text { agar plate that has been inoculated with a specified volume of a } \\
\text { known cell suspension of either Staph. aureus and } K \text {. pneumoniae } \\
\text { using a } 200 \text { g weight for } 1 \text { minute. The samples are then removed. } \\
\text { Replicate (3) samples are analysed for either the number of viable } \\
\text { bacteria or the total ATM content both before and after incubation } \\
\text { under humid conditions at } 37^{\circ} \mathrm{C} \text { for } 24 \text { hours. Samples are } \\
\text { sterilised prior to testing and a neutraliser is employed during cell } \\
\text { recovery. The test is validated by either growth of ^ } 1 \text { order of } \\
\text { magnitude during the incubation period or by a measure of the } \\
\text { variability of the data obtained. }\end{array}$ & $\begin{array}{l}\text { Cell suspension intimate } \\
\text { contact test. } \\
\text { Basic efficacy test that has } \\
\text { limited use as a simulation of } \\
\text { final use of a treated material. }\end{array}$ \\
\hline ISO 20743 & $\begin{array}{l}\text { Textiles - Determination of antibacterial activity of antibacterial } \\
\text { finished products: Printing method }\end{array}$ & $\begin{array}{l}\text { Replicate (6) samples of test material are either Staph. aureus and } \\
\text { K. pneumoniae by 'printing' cells collected on a membrane filter } \\
\text { onto their surface in a standardised manner. The samples are then } \\
\text { incubated under humid conditions for } 18-24 \text { hours at } 20^{\circ} \mathrm{C} \text { for a } \\
\text { specified contact time(s). Replicate (3) samples are analysed for } \\
\text { either the number of viable bacteria or the total ATM content both } \\
\text { before and after incubation. Samples are sterilised prior to testing } \\
\text { and a neutraliser is employed during cell recovery. The test is } \\
\text { validated by either determining the survival of the inoculum on the } \\
\text { control material. }\end{array}$ & $\begin{array}{l}\text { 'Dry' inoculum intimate } \\
\text { contact test. } \\
\text { The transfer method of } \\
\text { inoculation could be adapted } \\
\text { to provide some simulation } \\
\text { data. }\end{array}$ \\
\hline
\end{tabular}


Table VI: Methods used to Examine the Antimicrobial Activity of Textiles (fabric, yarn or pile/wadding)

\begin{tabular}{|c|c|c|c|}
\hline Reference & Title & Description & Major Principle \\
\hline ISO/FDIS 13629-1 & $\begin{array}{l}\text { Textiles - Determination of Antifungal Activity of Textile } \\
\text { Products: Part } 1 \text { - Luminescence Method }\end{array}$ & $\begin{array}{l}\text { Samples of textiles are inoculated with a suspension of fungal } \\
\text { spores either by direct application or transfer from an agar surface } \\
\text { and then incubated. Germination and growth of the spores is } \\
\text { followed by measuring the ATP concentration associated with the } \\
\text { samples. The presence of an antifungal treatment is expected to } \\
\text { show either an inhibition of germination or a reduction in the rate } \\
\text { of growth as indicated by reduced concentrations of ATP } \\
\text { associated with the treated material in comparison with the } \\
\text { untreated material. }\end{array}$ & $\begin{array}{l}\text { Basic efficacy test that has } \\
\text { limited use as a simulation of } \\
\text { final use of a treated material. } \\
\text { The transfer method of } \\
\text { inoculation could be adapted } \\
\text { to provide some simulation } \\
\text { data. }\end{array}$ \\
\hline ISO/WD 13629-1 & $\begin{array}{l}\text { Textiles - Determination of Antifungal Activity of Textile } \\
\text { Products: Part } 2 \text { - Plate Count Method }\end{array}$ & $\begin{array}{l}\text { Samples of textiles are inoculated with a suspension of fungal } \\
\text { spores either by direct application or transfer from an agar surface } \\
\text { and then incubated. Germination and growth of the spores is } \\
\text { followed by measuring the number of colony forming units. The } \\
\text { presence of an antifungal treatment is expected to show either an } \\
\text { inhibition of germination or a reduction in the rate of growth as } \\
\text { indicated by reduced numbers of colony forming units associated } \\
\text { with the treated material in comparison with the untreated material. }\end{array}$ & $\begin{array}{l}\text { Basic efficacy test that has } \\
\text { limited use as a simulation of } \\
\text { final use of a treated material. } \\
\text { The transfer method of } \\
\text { inoculation could be adapted } \\
\text { to provide some simulation } \\
\text { data. }\end{array}$ \\
\hline
\end{tabular}


Table VII: Methods used to Examine the Antimicrobial Activity of Carpets

\begin{tabular}{|c|c|c|c|}
\hline Reference & Title & Description & Major Principle \\
\hline " AATCC 174-2011 & $\begin{array}{l}\text { Antimicrobial Activity Assessment of Carpets } \\
\text { Qualitative Antibacterial Activity }\end{array}$ & $\begin{array}{l}\text { Petri dishes with nutrient media are inoculated with a single, } \\
\text { diagonal streak (approx. } 7.5 \mathrm{~cm} \text { ) of either Staph. aureus or } \\
\text { K. pneumoniae. An unsterilized test specimen ( } 25 \mathrm{~mm} \text { x } 50 \mathrm{~mm} \text { ) } \\
\text { is placed in intimate contact and transversely across the inoculum } \\
\text { on the agar surface. The plates are then inoculated at } 37^{\circ} \mathrm{C} \text { for } 18 \text { - } \\
24 \text { hours. The front and back of the carpet are tested separately. } \\
\text { After incubation, the plates are inspected for the presence of } \\
\text { growth both below the specimens and for any zone of inhibition } \\
\text { surrounding the specimens. The test can also be used to test the } \\
\text { effect of cleaning regimes. An untreated control is optional. }\end{array}$ & $\begin{array}{l}\text { Qualitative assessment of rate } \\
\text { of kill and zone diffusion test } \\
\text { Basic efficacy test that has } \\
\text { limited use as a simulation of } \\
\text { final use of a treated material. }\end{array}$ \\
\hline AATCC 174-2011 & $\begin{array}{l}\text { Antimicrobial Activity Assessment of Carpets } \\
\text { Quantitative Antibacterial Activity }\end{array}$ & $\begin{array}{l}\text { Unsterilized specimens of carpet are pre-wetted with either sterile } \\
\text { water or a wetting agent before being inoculated with individual } \\
\text { suspensions of either Staph. aureus or K. pneumoniae in either a } \\
\text { low or a high nutrient solution. The samples are then incubated in } \\
\text { a tightly closed jar at } 37^{\circ} \mathrm{C} \text { for a specified contact time. Cells are } \\
\text { recovered in } 100 \mathrm{ml} \text { of a neutraliser after } 0 \text { and } 6 \text { - } 24 \text { hours of } \\
\text { incubation. Activity is assessed by comparing the size of the initial } \\
\text { population in the control (if used) with that present following } \\
\text { incubation. A control is optional. When not employed, viable } \\
\text { counts following incubation of the treated specimens alone are } \\
\text { considered. The test can also be used to test the effect of cleaning } \\
\text { regimes. }\end{array}$ & $\begin{array}{l}\text { Cell suspension intimate } \\
\text { contact test. } \\
\text { Basic efficacy test that has } \\
\text { limited use as a simulation of } \\
\text { final use of a treated material. }\end{array}$ \\
\hline
\end{tabular}


Table VII: Methods used to Examine the Antimicrobial Activity of Carpets

\begin{tabular}{|c|c|c|c|}
\hline Reference & Title & Description & Major Principle \\
\hline AATCC 174-2011 & $\begin{array}{l}\text { Antimicrobial Activity Assessment of Carpets } \\
\text { Quantitative Antifungal Activity }\end{array}$ & $\begin{array}{l}\text { Petri dishes containing Sabouraud Dextrose Agar are inoculated } \\
\text { with } 1 \mathrm{ml} \text { of a spore suspension of Aspergillus niger. Immediately } \\
\text { afterwards, specimens ( } 38 \mathrm{~mm} \text { diameter) of unsterile test material } \\
\text { are placed into intimate contact with the agar. An additional } 0.2 \mathrm{ml} \\
\text { of the same spore suspension is also employed to inoculate the test } \\
\text { pieces directly. The samples are then incubated at } 28^{\circ} \mathrm{C} \text { for } 7 \text { days. } \\
\text { The back and front of the discs of carpet are tested in separate } \\
\text { dishes. The zone of inhibition and the growth of fungus on the } \\
\text { upper surface of the specimens are reported (no growth, } \\
\text { microscopic growth, macroscopic growth). The test can also be } \\
\text { used to test the effect of cleaning regimes. }\end{array}$ & $\begin{array}{l}\begin{array}{l}\text { Zone diffusion test/surface } \\
\text { growth test. }\end{array} \\
\text { Basic efficacy test that has } \\
\text { limited use as a simulation of } \\
\text { final use of a treated material. }\end{array}$ \\
\hline WIRA Test F & $\begin{array}{l}\text { Test Method for Assessing the Survival of Test Organisms on } \\
\text { Floor Coverings }\end{array}$ & $\begin{array}{l}\text { Specimens ( } 850 \mathrm{~mm} \text { x } 350 \mathrm{~mm} \text { ) are conditioned at } 20^{\circ} \mathrm{C} \text { and } 65 \% \\
\text { RH before being subjected to } 2 \text { wet and } 2 \text { dry passes using a } \\
\text { commercial spray extraction machine or a test rig. After } 24 \mathrm{~h} \\
\text { drying, } 12 \text { specimens (each } 60 \mathrm{~mm} \text { diameter) are cut from the } \\
\text { carpet. An aliquot ( } 1 \mathrm{ml} \text { ) of a suspension of cells of } E \text {. coli in } \\
\text { nutrient broth is poured onto filter paper ( } 7 \mathrm{~cm} \text { diameter). The filter } \\
\text { paper is then pressed for } 1 \text { min onto the surface of the carpet using } \\
\text { a } 1 \mathrm{~kg} \text { weight. The filter paper is then discarded. After } 0 \text {, } 6 \text { and } 24 \\
\text { hours incubation at a specified temperature the carpet's surface is } \\
\text { pressed onto contact plates of McConkey agar. After } 24 \mathrm{~h} \text { replicate } \\
\text { (3) plugs ( } 10 \mathrm{~mm} \text { ) are taken from each specimen and suspended in } \\
10 \text { ml nutrient broth for } 30 \text { seconds and then analysed for the } \\
\text { presence of } E \text {. coli by total viable count. }\end{array}$ & $\begin{array}{l}\text { Cell suspension intimate } \\
\text { contact test. } \\
\text { Potential to demonstrate the } \\
\text { effectiveness of an } \\
\text { antimicrobial treatment if } \\
\text { appropriate incubation } \\
\text { conditions are selected and } \\
\text { addition species employed. }\end{array}$ \\
\hline
\end{tabular}


Table VIII: Methods used to Examine the Antimicrobial Activity of Non-Porous Surfaces

\begin{tabular}{|c|c|c|c|}
\hline Reference & Title & Description & Major Principle \\
\hline "JIS Z 2801: 2000 & $\begin{array}{l}\text { Antimicrobial products - Test for antibacterial activity and } \\
\text { efficacy }\end{array}$ & $\begin{array}{l}\text { The surface of replicate sample ( } 3 \text { for each treatment and } 6 \text { for the } \\
\text { blank reference material - usually } 50 \mathrm{~mm} \times 50 \mathrm{~mm} \text { ) are inoculated } \\
\text { with a suspension of either } E \text {. coli or Staph. aureus in a highly } \\
\text { diluted nutrient broth. The cell suspension is then held in intimate } \\
\text { contact with the surface by the use of a sterile polyethylene film } \\
\text { (usually } 40 \mathrm{~mm} \times 40 \mathrm{~mm} \text { ) for } 24 \text { hours at } 35^{\circ} \mathrm{C} \text { under humid } \\
\text { conditions. The size of the population on the treated surface is then } \\
\text { compared with the size on the control surface both prior to and } \\
\text { after incubation. A neutraliser for certain biocide types is } \\
\text { employed. Antibacterial activity is certified if the difference } \\
\text { between the Log } \text { Lef }_{10} \text { of the population on the treated sample and that } \\
\text { on the control surface is }>2 \text {. }\end{array}$ & $\begin{array}{l}\text { Cell suspension intimate } \\
\text { contact test. } \\
\text { Basic efficacy test that has } \\
\text { limited use as a simulation of } \\
\text { final use of a treated material. }\end{array}$ \\
\hline ISO 22196:2011 & $\begin{array}{l}\text { Plastics - Measurement of antibacterial activity on plastics } \\
\text { surfaces. }\end{array}$ & $\begin{array}{l}\text { This is the current New Work Proposal at ISO created from JIS Z } \\
2801 \text { by the SIAA of Japan. Modification and validation is in } \\
\text { progress in collaboration with the IBRG. Some changes are } \\
\text { expected. }\end{array}$ & $\begin{array}{l}\text { Cell suspension intimate } \\
\text { contact test. } \\
\text { Basic efficacy test that has } \\
\text { limited use as a simulation of } \\
\text { final use of a treated material. }\end{array}$ \\
\hline XP G 39-010 & $\begin{array}{l}\text { Propriétés des étoffes - Étoffes et surfaces polymériques à } \\
\text { propriétés antibactériennes - Caractérisation et mesure de } \\
\text { l'activité antibactérienne }\end{array}$ & $\begin{array}{l}\text { Four replicate samples of test material are placed in contact with an } \\
\text { agar plate that has been inoculated with a specified volume of a } \\
\text { known cell suspension of either Staph. aureus and K. pneumoniae } \\
\text { using a } 200 \mathrm{~g} \text { weight for } 1 \text { minute. The samples are then removed. } \\
\text { Duplicate samples are analysed for the number of viable bacteria } \\
\text { both before and after incubation under humid conditions at } 37^{\circ} \mathrm{C} \\
\text { for } 24 \text { hours. A neutraliser is employed during cell recovery. }\end{array}$ & $\begin{array}{l}\text { Cell suspension intimate } \\
\text { contact test. } \\
\text { Basic efficacy test that has } \\
\text { limited use as a simulation of } \\
\text { final use of a treated material. }\end{array}$ \\
\hline
\end{tabular}


Table VIII: Methods used to Examine the Antimicrobial Activity of Non-Porous Surfaces

\begin{tabular}{|c|c|c|c|}
\hline Reference & Title & Description & Major Principle \\
\hline ASTM E2180-07 & $\begin{array}{l}\text { Standard Test Method for Determining the Activity of } \\
\text { Incorporated Antimicrobial Agent(s) in Polymeric or } \\
\text { Hydrophobic Materials }\end{array}$ & $\begin{array}{l}\text { Replicate (3) samples of material are inoculated with cells of either } \\
\text { Staph. aureus or K. pneummoniae suspended in molten semi-solid } \\
\text { isotonic saline/agar. This attempts for form an 'artificial biofilm' } \\
\text { which holds the suspension in intimate contact with the test surface } \\
\text { of inherently hydrophobic materials. Samples are then incubated at } \\
\text { a temperature similar to that intended for the final use for a } \\
\text { specified period (usually } 24 \text { hours) under humid conditions. The } \\
\text { size of the viable bacterial populations on the control and treated } \\
\text { surfaces is then determined using a dilution plate count. Any } \\
\text { effect is recorded using percent reduction calculated from the } \\
\text { geometric means of the data. A neutraliser may be employed and } \\
\text { sonication is used to separate the 'biofilm' from the test surfaces } \\
\text { and suspend the agar gel. Subsequent imprinting of the test surface } \\
\text { onto solid nutrient media can be performed to look for the presence } \\
\text { of adherent viable cells. }\end{array}$ & $\begin{array}{l}\text { Immobilised cell suspension } \\
\text { intimate contact test. } \\
\text { Basic efficacy test that has } \\
\text { limited use as a simulation of } \\
\text { final use of a treated material. }\end{array}$ \\
\hline ASTM E2149-10 & $\begin{array}{l}\text { Standard Test Method for Determining the Antimicrobial } \\
\text { Activity of Immobilized Antimicrobial Agents Under Dynamic } \\
\text { Contact Conditions }\end{array}$ & $\begin{array}{l}\text { Dynamic shake flask test. Test material is suspended in a buffer } \\
\text { solution containing a known number of cells of Klebsiella } \\
\text { pneumoniae and agitated. Efficacy is determined by comparing the } \\
\text { size of the population both before and after a specified contact } \\
\text { time. }\end{array}$ & $\begin{array}{l}\text { Relies on either diffusion of } \\
\text { antimicrobial agents from } \\
\text { treated material into the cell } \\
\text { suspension or due to } \\
\text { interaction between the } \\
\text { population and the surface of } \\
\text { the material in suspension. } \\
\text { Basic efficacy test that has } \\
\text { limited use as a simulation of } \\
\text { final use of a treated material. }\end{array}$ \\
\hline
\end{tabular}




\section{Appendix C: The Role of MIC Data in Supporting Claims for Treated Materials}

Although Minimum Inhibitory Concentration (MIC) data may not have a direct role in supporting claims and demonstrating the benefit of treated materials and treated articles, they can provide useful supporting information. For example, a treated material may have been shown to demonstrate effectiveness in reducing the viability of model Gram Positive and Gram Negative bacteria (such as E. coli and S. aureus) when delivered to a surface as a splash of contaminated liquid. MIC data may be available from the manufacturer of the active substance employed that demonstrates activity against a wide range of other bacteria at a similar level of sensitivity to the model species used in the efficacy simulation. It might be anticipated therefore that, provided that these species are morphologically and physiologically similar (i.e. they are not obligate anaerobes or species that produce endospores that can survive exposure), they will respond in a similar manner when exposed to the material under more realistic conditions. Caution needs to be taken when applying such a principle, and where a species is critical to a specific claim it should be employed in the efficacy test. However, MIC data can provide useful supporting information. 